\title{
The shifting landscape of LGBT organizational research
}

\author{
Michel Anteby*, Caitlin Anderson
}

Harvard University, USA

\section{A R T I C L E I N F O}

\section{Article history:}

Available online 18 September 2014

\section{Keywords:}

LGBT

Gay

Lesbian

Sexual minorities

Gender

Frame analysis

Discrimination

Workplace diversity

Organization studies

Organizational behavior

\begin{abstract}
A B S T R A C T
Over the past generation, sexual minorities-particularly lesbian, gay, bisexual, and transgender (LGBT) persons-have gained increased visibility in the public arena. Yet organizational research has lagged behind in recognizing and studying this category of organizational members. This article offers a critical review of this growing body of research. More specifically, we identify and discuss four dominant scholarly frames that have informed LGBT organizational research from the late nineteenth century to date. The frames include a "medical abnormality," "deviant social role," "collective identity," and "social distinctiveness" view of sexual minorities. We argue that these frames have profoundly shaped the scope and range of organizational scholarship devoted to sexual minorities by showing that scholars using such contrasted frames have been drawn to very different research questions with respect to sexual minorities. We document and discuss the main and contrasted questions asked within each of these frames and show how they have both enabled and constrained LGBT organizational research. We conclude by calling for more attention to the frames organizational scholars adopt when studying sexual minorities, but also for more research on both minority and majority sexual orientations in organizations.
\end{abstract}

(c) 2014 Elsevier Ltd. All rights reserved.

\section{Contents}

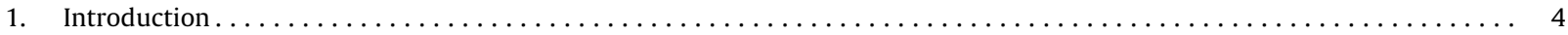

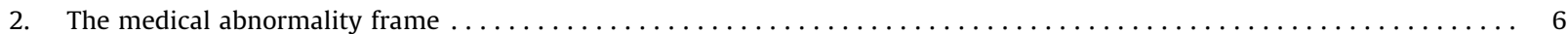

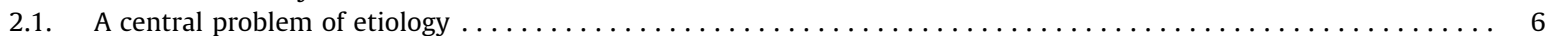

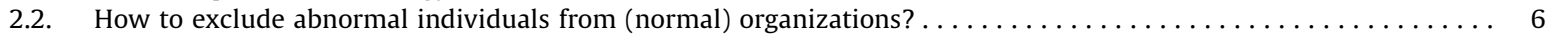

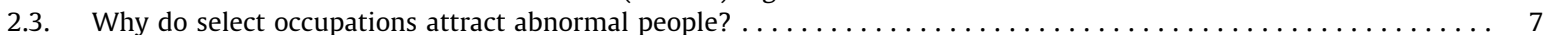

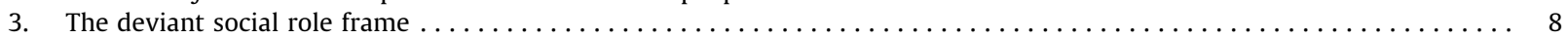

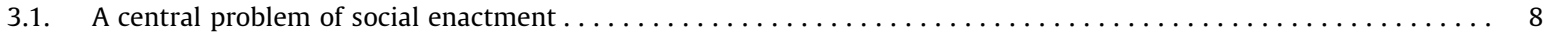

3.2. How are deviant social roles enacted outside formal organizations $\ldots \ldots \ldots \ldots \ldots \ldots \ldots \ldots \ldots \ldots$

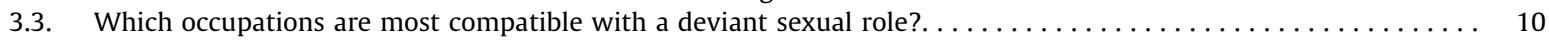

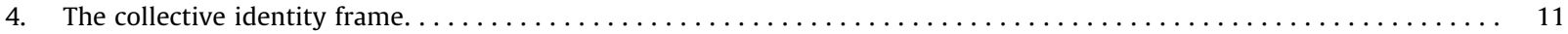

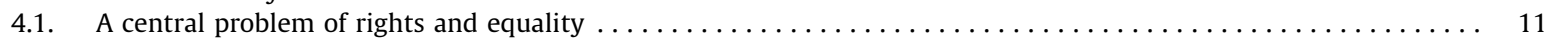

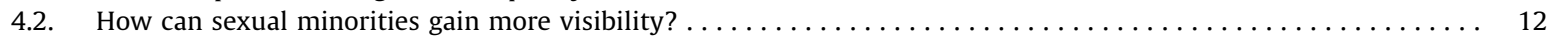

\footnotetext{
* Corresponding author at: Harvard Business School, Morgan Hall 321, Boston, MA 02163, USA. Tel.: +1 6174963756.

E-mail address: manteby@hbs.edu (M. Anteby).
} 


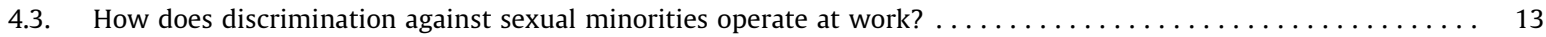

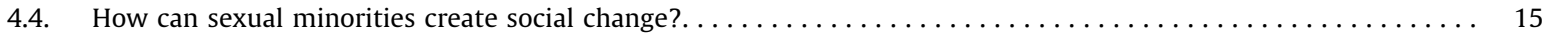

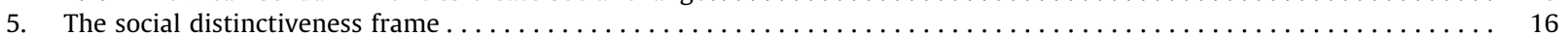

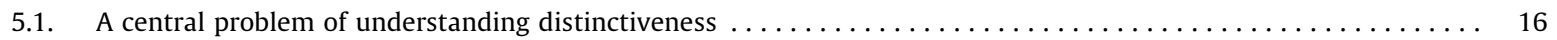

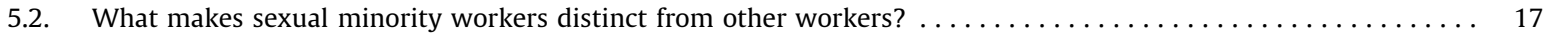

5.3. What makes organizations populated mainly by sexual minorities distinctive? $\ldots \ldots \ldots \ldots \ldots$

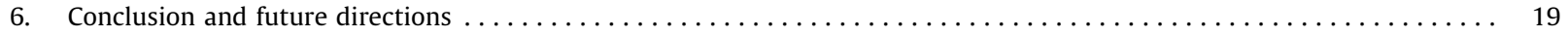

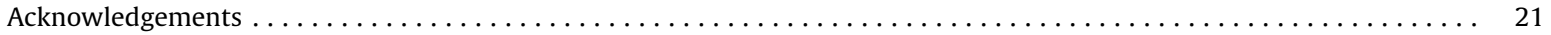

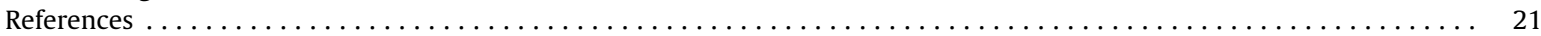

\section{Introduction}

Sexual minorities-particularly lesbian, gay, bisexual, and transgender (LGBT) persons-are a significant and increasingly visible constituency within organizations. As an example, a review of recent studies puts the number of lesbian, gay, bisexual, and transgender persons in the United States at approximately 9 million, or nearly 4 percent of the total population (Gates, 2011). Also, survey data collected as part of the U.S. National Longitudinal Study of Adolescent Health attest to both the magnitude and variety of this population: 7 percent of respondents report some degree of same-sex attraction and 2 percent claim a primarily or exclusively same-sex orientation (Harris, 2009). These numbers echo earlier results from a large-scale survey putting the percentage of respondents reporting either same-sex attraction or interest at 7.6 percent, and those identifying as gay, lesbian, bisexual, or transgender at 2.1 percent (Laumann, Gagnon, Michael, \& Michaels, 1994, p. 297).

Moreover, the above numbers are likely conservative estimates, as surveys continue to show that a significant proportion of LGBT individuals keep their sexual identities fully or partly concealed since disclosure in the workplace has been shown to lead to discrimination, termination, and even physical threats and attacks (D'Augelli \& Grossman, 2001; Deitch, Butz, \& Brief, 2004; Ragins \& Cornwell, 2001). Regardless of level of disclosure, sexual minorities are gaining visibility in the workforce. Many U.S. employers and legislatures have recognized this. In 1992, just two Fortune 500 companies offered same-sex partner benefits; in 2014, 67 percent offered these benefits. Though sexual minorities still lack formal protection on the federal level, 21 states, scores of municipalities, and 91 percent of Fortune 500 companies have included sexual orientation in employment nondiscrimination policies (Human Rights Campaign, 2014).

Despite their numerical force and their increasing public visibility, sexual minorities remain "one of the largest, but least studied, minority groups in the workforce" (Ragins, 2004, p. 35). The topic has been to a varying degree taboo in the social sciences in general (Taylor \& Raeburn, 1995) and management or organizational studies in particular (Creed, 2006; Githens, 2009; Williams \& Giuffre, 2011). Indeed, sexual minorities are scarcely visible in mainstream management scholarship: The twelve most highly cited journals in the field have published, between them, just ten articles referencing LGBTs in their title, key words, or abstract. Half of those journals have published none at all. ${ }^{1}$ Moreover, the limited research that exists is often scattered. It draws on multiple disciplines (e.g., sociology, social psychology, cultural history, social work, psychiatry, clinical and counseling psychology) and deploys a wide array of theoretical perspectives and methodological approaches.

Our aim in this article is twofold. First, our goal is to identify and review-despite its scarcity-past LGBT organizational scholarship ranging from the late nineteenth century to the present. By LGBT organizational scholarship, we mean studies dealing broadly with sexual minorities in organizations. ${ }^{2}$ Our goal is, therefore, to provide other scholars with a comprehensive review of what has been done to date. In addition, while organizational research tends to be somewhat atemporal (Daniel, Arzoglou, \& Lamont, 2011), we purposely foregrounded the date and the chronological sequence of the studies reviewed to provide an overview of the field's evolution. Indeed, the historical perspective we adopt here aims to use the past as a tool for sharpening our understanding of the present (Anderson, 2006; Halbwachs, 1980; Olick, 2007). This historical approach allows us to critically discuss the past, present, and possible future state of LGBT organizational research, but also draw implications more broadly for research on sexual orientations (including majority ones) in organizations.

Second, our aim in this article is to shed light on the largely un-acknowledged scholarly frames that have structured this research on sexual minorities, and show how these frames have shaped the type of research conducted. We define a scholarly frame as a set of interrelated ideas that, for a time, provides a model, problems, and solutions for a community of scholars to

\footnotetext{
1 The search was conducted in 2013 with the key words LGBT, GLBT, gay, lesbian, bisexual, homosexual, and same-sex benefits (with wildcards to catch variants) in the following twelve journals: Academy of Management Journal, Academy of Management Review, Administrative Science Quarterly, Journal of International Business Studies, Journal of Management, Management Science, MIS Quarterly, Organization Science, Research in Organizational Behavior, Strategic Management Journal, Journal of Applied Psychology, Organizational Behavior and Human Decision Processes. For details on the journal sampling see Battilana, Anteby, and Sengul (2010).

2 We use fairly interchangeably the terms "LGBT persons" and "sexual minorities" throughout our text, but we are well aware that little organizational scholarship examines bisexual and transgender individuals' experiences. Moreover, we are cognizant that the terms used to label sexual minorities has shifted significantly over time. For an example of such a shift, see Chauncey (1994, pp. 14-23).
} 
approach a given topic. Building on Erving Goffman's terminology (1974, pp. 10-11), this frame of interrelated ideas is a situational definition constructed in accord with organizing principles that govern both the events themselves (here, the research pursuits) and participants' experiences of these events (the scholars' experiences of the pursuits). A frame determines, for instance, what is to be researched and the kind of questions that can be asked. Like in fantasy games, scholarly frames of interrelated ideas provide a "make-believe" world in which participants implicitly or explicitly agreed to a set of rules that govern their beliefs and actions (Fine, 1983).

With respect to sexual minorities, successive frames tend to be defined by what has been called the "central problem" of the subfield: namely, how to define the population under review (Hekma, 2007). The answer to this question, as we will show, dictates in part the type of scholarship produced. Just as policy and socially acceptable attitudes toward LGBT persons have changed considerably in the recent past, scholarly frames too have changed considerably. We suggest that LGBT organizational research from the late nineteenth century to the present is best understood within a shifting landscape that distils changing definitions of the population being studied. This shifting landscape consists of four frames that have, mostly sequentially, dominated the research agenda. The frames include "medical abnormality," "deviant social role," "collective identity," and "social distinctiveness" views of sexual minorities. (See Table 1 for an overview of the four frames.) We detail these frames below and show how they have profoundly shaped organizational scholarship on sexual minorities.

This schema of scholarly frames allows us to make two contributions to organizational research. First, we provide a more structured language to make sense of and critically examine organizational scholarship on sexual minorities.
As an illustration, an understanding of the thematic preoccupations of scholarly frames is particularly useful in explaining why certain populations, research sites, and questions have received considerable attention while others have not. This feature makes our frames particularly useful in our second contribution: to stimulate innovative work on sexual orientation more broadly in organizations. As stated above, sexual minorities remain understudied, and we wish to encourage more research on the place and impact of sexual minorities in organizations. Yet we also suggest that innovative research can come from rethinking the scholarly frames in which sexual orientation more broadly is studied. In this, as in all areas of inquiry, new paradigms ask new questions of old data, move beyond the mere filling-out of the previous paradigm, and rewrite the map directing new research. We suggest, for example, that viewing a minority sexual orientation with a given frame raises also questions on sexual majority orientations in organizations. Indeed, with the exception of sexual harassment, there seems to be little empirical research on sexual majorities in organizations, and few frames to approach them. We hope that this article will not only open new paths of research on sexual minorities, but also on sexual majorities in organizations.

The article is organized as follows: For each frame that we identified (e.g., medical abnormality), we first focus on and discuss the central problem the frame addresses. Some literature reviewed in this section can lie outside the boundaries of organizational research per se (e.g., psychiatry), but is included because it strongly informs how organizational scholars reliant on the given frame have studied sexual minorities. In a second step within each frame, we detail and discuss the key questions with organizational implications that have attracted the most scholarly attention (e.g., how to exclude abnormal individuals from "normal" organizations in a medical

Table 1

Scholarly frames used to study sexual minorities in organizational research.

\begin{tabular}{|c|c|c|c|c|}
\hline Frame & Medical abnormality & Deviant social role & Collective identity & Social distinctiveness \\
\hline Period & $1860 s-1960 s$ & $1960 s-1980 s$ & 1970s-present & 2000-present \\
\hline $\begin{array}{l}\text { Population's } \\
\text { definition }\end{array}$ & $\begin{array}{l}\text { Population defined by a } \\
\text { medical or psychiatric } \\
\text { pathology, either present } \\
\text { from birth (genetic or } \\
\text { congenital) or fixed in early } \\
\text { childhood thanks to } \\
\text { abnormal development. }\end{array}$ & $\begin{array}{l}\text { Population defined by the } \\
\text { assumption of a deviant } \\
\text { social role and participation } \\
\text { in deviant sexual practices. }\end{array}$ & $\begin{array}{l}\text { Population defined as a } \\
\text { comparatively stable and } \\
\text { bounded minority group } \\
\text { identity analogous to a } \\
\text { minority ethnic identity }\end{array}$ & $\begin{array}{l}\text { Population defined according } \\
\text { to a variety of criteria and } \\
\text { compared in studies to a } \\
\text { variety of other populations }\end{array}$ \\
\hline $\begin{array}{l}\text { Comparison } \\
\text { groups studied } \\
\text { alongside the } \\
\text { population }\end{array}$ & $\begin{array}{l}\text { - Hysterics, hypochondriacs } \\
\text { - Alcoholics and addicts } \\
\text { - Neurotics }\end{array}$ & $\begin{array}{l}\text { - Juvenile delinquents } \\
\text { - Illegal drug abusers } \\
\text { - Rapists }\end{array}$ & $\begin{array}{l}\text { - African Americans } \\
\text { - Women } \\
\text { - Minorities }\end{array}$ & $\begin{array}{l}\text { - Much broader range: for } \\
\text { instance, people with a } \\
\text { select gene or with a } \\
\text { concealable stigma }\end{array}$ \\
\hline Central problem & $\begin{array}{l}\text { - The etiology of sexual } \\
\text { abnormality }\end{array}$ & $\begin{array}{l}\text { - The social role enactment of } \\
\text { a deviant sexuality }\end{array}$ & $\begin{array}{l}\text { - The rights and equality of } \\
\text { sexual minorities }\end{array}$ & $\begin{array}{l}\text { - The distinctiveness of } \\
\text { sexual minorities }\end{array}$ \\
\hline $\begin{array}{l}\text { Key research } \\
\text { questions }\end{array}$ & $\begin{array}{l}\text { - How to exclude abnormal } \\
\text { individuals from (normal) } \\
\text { organizations? } \\
\text { - Why do select occupations } \\
\text { attract abnormal people? }\end{array}$ & $\begin{array}{l}\text { - How are deviant social roles } \\
\text { enacted outside formal } \\
\text { organizations? } \\
\text { - Which occupations are } \\
\text { most compatible with } \\
\text { deviant social roles? }\end{array}$ & $\begin{array}{l}\text { - How can sexual minorities } \\
\text { gain more visibility } \\
\text { - How does discrimination } \\
\text { against sexual minorities } \\
\text { operate at work? } \\
\text { - How can sexual minorities } \\
\text { create social change? }\end{array}$ & $\begin{array}{l}\text { - What makes sexual } \\
\text { minority workers distinct } \\
\text { from other workers? } \\
\text { - What makes an } \\
\text { organization populated } \\
\text { mainly by sexual minorities } \\
\text { distinct? }\end{array}$ \\
\hline
\end{tabular}


abnormality approach). In doing so, we continuously contrast and compare the frames to highlight the differences and similarities in approaches to the organizational study of sexual minorities. We start with the earliest frame that scholars adopted, namely the medical abnormality one, and end with the most contemporary one, namely, the social distinctiveness frame.

\section{The medical abnormality frame}

\subsection{A central problem of etiology}

From the start, research on gender role inversion and same-sex sexual behavior had implications for organizational research, though these implications were typically subordinated to the early literature's overwhelming concern with the origins, or etiology, of homosexuality. The earliest "scientific" research on homosexuality-as opposed to the moral or legal literature that constituted most earlier, nonscientific writing on the subject-viewed same-sex sexual behavior as an abnormal physical or psychiatric condition. ${ }^{3}$ An article written in 1870 by a German neurologist and psychiatrist and titled "Contrary Sexual Feelings"-credited by Michel Foucault to mark the birth of the "modern" homosexual-illustrates well such a view. The article describes two people dealing with homosexual feelings and presents them as a psychiatric abnormality. We use the broader term of "medical" (rather than only psychiatric) abnormality to describe such an approach to sexual minorities since the etiology or "contrary" origins of the abnormality were often open to contestation.

Nineteenth- or early twentieth-century "sexologists" disagreed as to whether sexual orientation was a biological anomaly (Ellis, 1897) or a function of abnormal psychiatric development [e.g., Group for the Advancement of Psychiatry (1955)], but both perspectives had the same implications for the conceptualization of sexual minorities. Indeed, proponents of both perspectives were primarily concerned with etiology. The study of other aspects of the social lives of sexual minorities was accordingly conceived as a secondary endeavor; the marshaling of supporting evidence for the assertion that an individual's nature as an abnormal "invert" or "homosexual" was either biological or fixed in very early childhood. Also, proponents of both perspectives tended to be comparatively sympathetic to sexual minorities: despite their differences, both emphasized the involuntary aspect of homosexuality and urged compassion rather than criminalization or condemnation. ${ }^{4}$

Studies associated with the medical abnormality frame can be broken down into one of two empirical streams. Both streams tried to answer the questions of "origins" even though their methodologies are highly problematic by late twentieth- or early twenty-first-century standards. The first stream was typically performed upon inmates of

\footnotetext{
${ }^{3}$ For discussions of legal and moral aspects of homosexuality, see for instance, Boswell (1980), Lever (1985), and Brooten (1996).

${ }^{4}$ For an exception, see Lichtenstein (1921), who urges indefinite solitary confinement for anyone who accepts same-sex sexual advances.
}

institutions: hospitals, orphanages, prisons, mental asylums, and the like. (Subjects did not need to be informed about the goals, or even the existence, of a study.) Some studies, like the physiologist Eugen Steinach's infamous testicular transplants (aiming to correct the "origin" of the abnormality), were both invasive and extremely physically/emotionally damaging (Steakley, 1997, p. 147). The second stream of research appropriated the case study method typical of medical research, offering narrative histories of patients. The case history method offered a somewhat less biased sample, as it included individuals who had voluntarily submitted to treatment in addition to the inmates of institutions, but it was still far from representative. In the case of sexuality research, however, the roster of case studies was supplemented to some extent by correspondence from individuals who had read a scholar's work, sought him out, and told him their stories. This was particularly true of the British physician Havelock Ellis (1897), one of the first physicians to write about "sexual inversion." As the cataloguer of his extensive papers observed, "[w]omen and men wrote to Ellis literally in their thousands, throughout his long life. Some wrote to him as a doctor who might cure them of their diseased condition; all wrote as to a friend whom they could trust not to censure them for their fantasies" (Summers, 1991, p. 180). Accordingly, such case histories offer some of the earliest information about non-institutionalized, selfidentified sexual minorities, told-if not in their own words-at least by a comparatively sympathetic listener, making the "sexologists" the sources of some of the earliest information on the working lives of sexual minorities.

Yet for most scholars operating within the medical abnormality frame, the notion that a sexual minority could populate any normal workplace hardly registered on their research agenda. In fact, the first main line of inquiry on sexual minorities with organizational implications in this approach concerned itself with trying to exclude them from "normal" organizations. In the few instances when scholars did notice a concentration of sexual minorities (particularly in select occupations), the key question then became how to explain the anomaly. We detail next these two main research questions, which proved central to organizational research in the medical abnormality frame.

\subsection{How to exclude abnormal individuals from (normal) organizations?}

The medical paradigm that prevailed in LGBT research for at least the first half of the twentieth century helps explain the invisibility of gays and lesbians within organizations during that time. If sexual minorities are understood as abnormal, damaged individuals, then it followed that few would be able to function highly enough to be members of any organization other than mental institutions or the like-a conclusion circularly reinforced by the fact that a large proportion of research on sexual orientation used already-institutionalized individuals as subjects. Thus, the main organizational research question pursued at that time was mainly an instrumental one: How to ensure that abnormal individuals did not populate "normal" organizations. 
The efforts of applied psychologists to devise a psychological screening test to aid in identifying and excluding sexual minorities illustrate the way this research question played out in scholars' research agendas. The World Wars were the defining events in this process. The experience of the First World War made army officials and others aware that there existed a significant proportion of gay men who could successfully pass as straight under normal circumstances. These men, it was believed, would crack under the pressure of combat and the enforced gregariousness of military life and become costly "psychological casualties” of war (Abrams, 1918; Bérubé, 1990, pp. 10-16). As part of mobilization for the Second World War, American psychiatrists attended seminars instructing them in the principles behind the nationwide mass psychiatric screening. "Seminar lecturers described gay men exclusively within the context of mental illness, referring to them as clinical cases rather than as members of a social group" (Bérubé, 1990, p. 19). Early guidelines instructed officials to look for effeminate mannerisms, aberrant body parts, and excessive modesty; later tests were more standardized. One paper-and-pencil test developed in 1943, the Cornell Selectee Index, used occupational choice questions to identify "effeminate" selectees: men who expressed interest in careers in interior decorating, dancing, or window dressing were thought to have difficulty with their "acceptance of the male pattern" (Weider, Mittelmann, Wechsler, Wolff, \& Meixner, 1944). These tests' main goal was to weed out "abnormality" from the military forces.

After war's end, such tests and others were adapted for civilian life. Researchers generated lists of "signs" of homosexuality in the Rorschach, Draw-a-Person, and other widely used psychological tests (Davids, Joelson, \& McArthur, 1956; Reitzell, 1949; Wheeler, 1949; Whitaker Jr., 1961); one test described in the Journal of Applied Psychology in 1959 proposed a "femininity adjective checklist" that scored individuals along a "femininity scale"; self-identified homosexuals apparently scored higher than both the male and female control groups (Berdie, 1959). To the extent that organizational researchers took note of sexual minorities, then, it was mainly in the context of an effort to keep them out of the workplace. Yet some scholars could not help but notice a puzzling concentration of sexual minorities in select lines of work: a motivation for the second line of inquiry within the medical abnormality approach.

\subsection{Why do select occupations attract abnormal people?}

As the vocational checklists suggest, the most common line of sexuality research with organizational implications concerned the relationship between sexual orientation and choice of occupation. Researchers working within the medical paradigm perpetuated, in particular, one of the more durable tropes about the work lives of gay men: the association with creative occupations. (There was little if anything at that time in the literature about the occupational interests of lesbians, mirroring the comparative lack of interest in the vocational interests and aptitudes of women in general.) Following the more obscure German medical research (e.g., von Krafft-Ebing, 1886), Ellis (1897) devoted considerable space to the overrepresentation of gay men in the arts, particularly literature and music. His analysis echoed contemporary theories of genius, which likened it to a form of madness. "The congenitally inverted may," he wrote, "be looked upon as a class of individuals exhibiting nervous characteristics which, to some extent, approximate them to persons of artistic genius" (Ellis, 1897, p. 294). ${ }^{5}$

In subsequent decades, researchers continued to design studies probing the relationship between male homosexuality and creative or artistic aptitude (Bailey \& Oberschneider, 1997; Fenichel, 1946; Green \& Money, 1966). Conclusions varied from those that dismissed the idea that homosexuality could convey any particular strengths at all (Ellis, 1959) and those arguing that a creative bent was innate or at least present at an early age (Green \& Money, 1966, p. 535). Researchers' explanations varied along with their particular theoretical allegiances and often veered toward the highly speculative: for example, the Freudian psychoanalyst Edmund Bergler (1960) claimed that homosexual men became fashion designers so that they could vent their resentment of women in the form of painful and restrictive clothing. ${ }^{6}$

Yet the medical abnormality frame was at a loss to explain the much higher observed incidence of homosexual contact in occupations segregated by sex, such as boarding schools, military forces, or prisons (Chauncey, 1994, p. 91). Indeed, female homosexuality appeared to be particularly closely associated with workplaces dominated numerically by women. "Female inversion," Ellis (1895, p. 146) wrote, was "specially fostered by those employments which keep women in constant association, not only by day but often at night also, without the company of men." Service as a hotel maid was apparently once thought to create lesbians, to the degree that some private households refused to employ former hotel maids as domestics. Seamstresses, lacemakers, and other garment workers "confined for long hours in close contact to one another in heated rooms" were also suspect, and the conviction that prostitutes were likely to be or become lesbian was also widespread. As Ellis admitted, evidence that sexual behavior could be acquired "seems in opposition to all that we know concerning the

\footnotetext{
${ }^{5}$ Another concentration noted by Ellis was an overrepresentation of homosexual men in hairdressing and medicine. He explained it by the supposedly desirable "close physical association" that barbers or physicians have with their clients or patients (Ellis, 1897, p. 294).

${ }^{6}$ As a way perhaps to counter such speculative typecasting, occupational questions figured prominently in surveys circulated among members of the nation's two most extensive lesbian and gay societies in 1958 and 1959, with the stated purpose of encouraging further research. Though admittedly small and unrepresentative $(N=157)$, the 1958 survey of lesbian subscribers to the Daughters of Bilitis newsletter found that both educational level and income of the group were well above average, and that professionals were far more highly represented in the group than among American women as a whole ("Some facts about lesbians," 1959). The survey of men the following year $(N=100)$ found that though the educational level of Mattachine newsletter subscribers was higher than that of the average American male, their income level was considerably lower ("Some comparisons between male and female homosexuals," 1960).
} 
existing causes of homosexuality," but still explanations were needed for such puzzling perceived concentrations.

Such evidence that individual variation in sexual orientation could be, at least in part, a function of social experiences, weakened the explanatory power of the medical abnormality frame on sexual minorities. A second and more direct challenge seriously undermined the assumption, central to this perspective, that gay men and women were damaged individuals, largely incapable of functioning in mainstream organizations. This was the work of psychologist Evelyn Hooker, who in 1957 published the results of one of the first studies ever conducted on gay men who were neither institutionalized nor seeking psychiatric treatment (1957). She gathered two groups of men, one of self-identified homosexuals and the other of professed heterosexuals, closely matched for occupation, educational level, and intelligence quotient, and administered to both groups a battery of psychological tests. Not only were experienced readers of the Rorschach and other tests unable to detect the sexuality of either group based solely on their test transcripts, but both groups scored equally well on indices of "psychological health." Hooker's results suggested that the link between homosexuality and mental illness was a false correlation produced by the reliance on institutionalized subjects and led the way for the eventual de-pathologizing of homosexuality by the psychiatric profession in 1974.

Her results also had implications for the study of LGBT individuals in organizations, for-in addition to the psychological implications-her findings suggested not only that gay men and women could be present, covertly, in mainstream organizations, but also that there existed several "sectors" of social life that did not, or need not, intersect with one another. She concluded that even if "homosexuality represents a severe form of maladjustment to society in the sexual sector of behavior, it does not necessarily mean that the homosexual must be severely maladjusted in other sectors of his behavior" (Hooker, 1957, pp. 30-31). The implication was clear: the welladjusted homosexual was a compartmentalized one, but this also meant that a well-adjusted "abnormal" person could also populate the workplace as long as he or she sufficiently compartmentalized his or her abnormality. This possibility explains in part the rise of a second framenamely, the "deviant social role"-to account for LGBT individuals' presence and behavior in organizations.

\section{The deviant social role frame}

\subsection{A central problem of social enactment}

The notion of discrete "sectors" of an individual's behavior (Hooker, 1957, pp. 30-31) was central to the social role research frame that emerged in partial reaction to the medical abnormality frame. This alternate social role frame gained prominence in research published from the late 1960s through the early 1980s, particularly in sociology and anthropology. It regarded lesbians and gay men not as individuals suffering from a pathology but as enactors of a "social role," one among many that an individual could hold across various spheres of life and within a lifetime. Scholars working in that tradition readily acknowledged the existence of a large palette of roles, but still noted that sexual minorities held deviant roles compared to those of the sexual majority.

A pair of empirically grounded articles published in 1967 and 1968 in the United States and Great Britain, respectively, laid out this new social role paradigm. The authors of the first piece, William Simon and John Gagnon (1967), drew their inspiration from survey research undertaken at the Kinsey Institute for Sex Research, founded in Bloomington, Indiana, in 1947. In contrast to earlier ways of thinking about sexuality as biological, bodily, and "natural," Simon and Gagnon instead emphasized the extent to which the sexual was contained within the social. As John Gagnon later wrote, "[t]he novelty of what we did then was to lay a sociological claim to an aspect of social life that seemed determined by biology or psychology" (1990, p. 231). When individuals acted sexually, they were posited to draw on the "sexual scripts" available to them at their particular location in time and space. The notion of sexual scripts allowed Gagnon, Simon, and their followers to understand sexuality as the interplay of internal factors with the social roles, cues, and material conditions available to an individual in her or his particular circumstances (Gagnon, 1974; Simon \& Gagnon, 1967). The following year, the English sociologist Mary McIntosh (1968) drew similar conclusions from historical and anthropological evidence. Sexual categories, she argued, varied tremendously across time and place. Rather than taking the social existence of the homosexual role for granted, McIntosh, Gagnon, Simon and others turned it into a problematic issue to be examined. Thus, the central problem for the field became understanding sexual minorities' enactment of their social roles.

The social role and script approach to sexuality demanded reevaluation of all human sexual behavior, but it had particularly wide-reaching implications for the study of sexual minorities. The promise of the new perspective in particular on same-sex desire was that it liberated researchers from what Simon and Gagnon called the sexologists" "obsessive" focus on "the most difficult and least rewarding of all questions, that of etiology" (1967, p. 177). Previously, the standard causal question in the study of homosexuality asked what made people homosexual. The social role perspective asked, instead, how sexual minorities enacted their social roles. It was essentially agnostic as to original causes. For example, homosexuals were not people with unhealthy relationships with their mothers, or abnormal genes, endocrine levels, or fetal development; they were simply those who labeled themselves-or, perhaps more significantly, were labeled by others-as such (Plummer, 1982). Accordingly, most research within this frame was based on the presumption that the particular social forms and patterns of interaction of LGBT individuals in organizations were a function of the hostility, disapproval, and persecution of the broader society (Leznoff \& Westley, 1955; Whitam, 1977, 1986). Indeed, sexual minorities were not only enacting a specific social role, but also one that the sexual majority deemed deviant: it is telling that researchers in this tradition borrowed references and theoretical insights 
from studies on social deviants, such as juvenile delinquents or users of illegal drugs (Leznoff \& Westley, 1955).

The deviant social role frame significantly opened the possibilities for LGBT organizational research. A medical abnormality, whether psychiatric or somatic, is a permanent disfigurement; possibly concealable at times, but always informing behavior and presumably disqualifying the sufferer from membership in mainstream organizations. Social roles, by contrast, were in theory far more easily compartmentalized. Role theory, whether in its functional, structural, or symbolic interactionist form, presumes that individuals play multiple roles, with many entrances and exits, throughout their lifetimes and within their varied social worlds. A deviant role can, like a coat, be checked at the door. In a sense, the social role frame provided an explanation for Albert Kinsey's suggestion that there existed a large, closeted gay and lesbian population (some 38 percent of his male and 13 percent of his female respondents claimed same-sex sexual experience), and Kinsey estimated that about 10 percent of the American public was primarily or exclusively homosexual (Kinsey, 1948). If a person holds multiple social roles, some of these need not be enacted at work, in school, or in other traditional social settings.

Combined, the conception of a minority sexual orientation as a social role and Kinsey's estimate of their presumed numbers suggested that members of this population had as varied and extensive an organizational life as anyone else. Indeed, Simon and Gagnon urged scholars of homosexuality to abandon the near-exclusive focus on the sexual behavior of lesbians and gay men, and investigate the full range "of forces, both sexual and nonsexual, that impinge on this individual actor" (1967, p. 179), singling out the work life of gay men and lesbians as a particularly fruitful area of research.

In a deviant social role frame, organizational research on sexual minorities took on two main and novel questions. Scholars' efforts focused, first, on understanding how these roles could be enacted outside formal organizations and, second, on identifying occupations that proved most compatible with such role enactment. Put otherwise, once scholars gained a better understanding of sexual minorities' mostly "underground" social role enactments, they tried to identify the most likely occupations that allowed their members to participate in such social scenes. We detail next these two questions.

\subsection{How are deviant social roles enacted outside formal organizations?}

In contrast to the medical abnormality perspective, which took the individual as the unit of analysis and emphasized psychological forces internal to the individual, the emergence of a more sociological perspective on sexual minorities foregrounded the organization (albeit still informal) as a unit of analysis. The notion of a "gay organization" made sense within the deviant social role framework, in a way that it did not for researchers who defined their population as dysfunctional or sick individuals. But because a deviant sexual role was, by necessity, a private-indeed secret-role, the organizations available for study were necessarily informal and equally secret.
For the most part, thus, the studies to which the social deviant frame gave rise were fine-grained field studies of the informal and often underground organizations of the gay and lesbian community: bars (Achilles, 1967; Lapovsky Kennedy \& Davis, 1993; Reitzes \& Diver, 1982; Taub, 1982), social cliques (Leznoff, 1956; Leznoff \& Westley, 1955), strip-dance clubs and sex paraphernalia shops (McCaghy \& Skipper, 1969; Perkins \& Skipper, 1981), bathhouses (Weinberg \& Williams, 1975), prostitution rings (Reiss, 1961), cruising grounds (Humphreys, 1975), and other underground social worlds. These studies offered a more sustained observation and analysis of phenomena long noted by law enforcement officers: the existence of secret societies or gathering spaces for homosexuals, like those identified as early as the seventeenth century at the French Royal Court or in select Parisian neighborhoods (Lever, 1985).

Throughout, the dominant theme of these updated field studies was that of deviance, and the ways in which informal organizations emerged to manage and deflect the stigma that deviance carried with it. For instance, Nancy Achilles' (1967) study of San Francisco gay bars built on Donald Webster Cory's (1951) earlier observation that gay bars, despite their risk of closure by the authorities, lent a crucial "aura of respectability" to the city's gay subculture: "the drinks, the music, and the atmosphere of friendliness [at bars] give a far less outlawed aspect to sex" (1951, p. 120). In addition, gay bars assumed duties that were more than social: some served as informal lending institutions to patrons in need, many ( particularly neighborhood establishments)also functioned as a corner store so that patrons could purchase milk and other necessary articles without needing to put their public, "straight" face back on (Achilles, 1967). Another recurring theme was the ways in which public roles and organizations structured the informal organizations in which sexual deviants could enact their private roles.

There was another organizational angle, too, to the deviant social role frame. It focused attention on the ways that standardized social cues, role-playing, and material conditions-all features of organizations-influenced the expression of sexuality. Whereas the medical abnormality frame viewed sexual orientation as a more or less fixed category, the emphasis on social context gave rise to the notion of "situational homosexuality," which emerged when individuals encountered organizational settings that permit or reward homosexual behavior (Gagnon, 1974; Simon \& Gagnon, 1967). The prison was the archetypal site for situational homosexuality, but certain work organizations and occupations qualified as well, from merchant ships and lumber camps to prostitution rings and burlesque dance halls. For example, a study in a women's prison found a higher rate of lesbians among incarcerated prostitutes than among other occupations (Ward \& Kassebaum, 1964), as did an ethnographic study of strippers (McCaghy \& Skipper, 1969). These findings led scholars using the social role frame to stress, "the importance of situational conditions as explanatory variables for understanding rates of deviant behavior" (McCaghy \& Skipper, 1969, p. 269).

Similarly, the theory of sexual scripts fractured the medical abnormality paradigm's uniform category of "homosexual" into a large number of situational social types. Laud Humphreys' (1975) landmark study of casual 
male-to-male sex in public restrooms, for example, carefully described the various roles that participants could play, both sexual and not. In fact, Humphreys' most controversial discovery was that a large proportion of tearoom habitués were not in fact self-identified members of the gay community. ${ }^{7}$ Similar studies on teenage male prostitutes and the organization of impersonal sex at a highway rest stop added innumerable further categories (e.g., the bar-hustler, the street-hustler, the call-boy) to the list of possible sexual roles (Corzine \& Kirby, 1977; Goode, 1974; Reiss, 1961). Importantly, all these roles could coexist with more traditional ones (e.g., a father, a student, a sales clerk). This coexistence raised the issues of role compatibility: the second main research question pursued by scholars working in the social role tradition.

\subsection{Which occupations are most compatible with a deviant sexual role?}

In the social role perspective, any sexual role-and especially a minority sexual role-was necessarily a private social role, a mask that an individual could raise and drop as he or she moved between social worlds. Thus, what little research on sexual minorities within occupations that did exist at the time focused on identifying the jobs and professions best suited to gay men and, a lesser extent, lesbians. For example, a 1952 doctoral thesis in education defended at New York University surveyed the "vocational interests of a group of [male] homosexuals," explaining that sexual orientation was "a significant part of selfconcept" and such information would be helpful for sexual minorities hoping to "participate more fully in economic life" (Haselkorn, 1953).

Most research was dominated by the assumption that gay and lesbian workers needed to maintain separate spheres in their lives-the public, organizational sphere where they played a straight role, versus the private realm of intimacy, where they could enact their deviant sexual role. In 1957, for example, the Chicago chapter of the Mattachine Society hosted an ongoing discussion series on "the effect of sexual deviation on job relations," in which panelists urged their members to shun "employment situations in which he must rely heavily upon heterosexual social contacts to be successful," particularly recommending traveling positions such as sales jobs ("The invert and his job," 1955, p. 15). Also, Simon and Gagnon urged researchers to take up the question of "the effects of a deviant sexual commitment upon occupational activity itself." For example, they suggested, "the ability of some jobs to facilitate homosexual activity-such as certain marginal, low-paying, white-collar jobs-might serve as compensation for low pay or limited opportunity for advancement" (1967, p. 184). Similarly, Humphreys (1975) found that a significant proportion of the tearoom habitués had gravitated toward occupations that allowed them a sufficient degree of freedom and autonomy to permit their "deviant" activities.

\footnotetext{
${ }^{7}$ Humphreys' (1975) work is often singled out today for its use of deception and its lack of informed consent. The study remains nonetheless an extremely well-informed dive into tearoom trade.
}

Despite the frequent insistence on the separate social worlds of work and intimacy, some researchers found evidence that the two were mutually constitutive. For example, sexual minorities' work situation was not only affected by their orientation, but their occupations in turn shaped their informal organizations (Leznoff \& Westley, 1955). Research conducted in a large Canadian city found that the type of occupation, and its degree of tolerance of a non-majority sexuality, played a constitutive role in the inner workings of the "homosexual community" in the city they studied. Some occupations, mainly professional and managerial, seemed to exhibit a low tolerance for sexual minorities. By contrast, in other occupations, gay men could be more open: these included occupations that were traditionally coded as gay jobs (e.g., artists, hairdressers, interior decorators) or that were of sufficiently low status that sexual minorities could be tolerated (e.g., counter-man, bell-hop). Maurice Leznoff and William Westley (1955) found that gay men in professional and managerial positions sought out the company of gay men in similar positions who shared their low tolerance for disclosure. A gay closeted lawyer, for example, expressed fear and disdain for those in other occupations who were more open, "I know a few people who don't care. They are really pitiful .... A lot of the artists don't care. For that reason I have never cultivated the friendship of artists" (1955, p. 261). Individuals in positions that did not require concealment, by contrast, sought out the company of other men with whom they could be comparatively free and open. In at least one case, upward mobilityfrom salesman to manager at an appliance shop-led one man to switch role affiliations (from openly gay to closeted).

Scholars' focus on identifying occupations amenable to sexual minorities' social role enactment was so prevalent at the time that one of the lone opponents of the "social role" view on sexual minorities conducted research on occupational segregation of gay men in an effort to debunk it. Frederick Whitam engaged in cross-cultural field research in Brazil, Central America, New York, and the Philippines in an effort to prove that sexual identitiesincluding inclinations toward particular careers-were fixed in early childhood and shared across cultures, rather than socially enacted and constructed (Whitam \& Dizon, 1979). The very notion of a "social role," Whitam argued, presumed the pre-existence of a particular prescription for behavior in the social structure, and a mechanism for assuming that role-either an external socialization process, or a voluntary decision to enact it. In Whitam's (1977) view, the fact that homosexuality existed in similar forms (including similar occupational clustering) across multiple distinct cultures that actively discouraged it rendered absurd the notion of a "homosexual role" and instead pointed to early predispositions. Whitam's work provoked not one but several publications designed specifically to refute his findings-a sign of the pervasiveness of the social role view at that time. ${ }^{8}$

\footnotetext{
${ }^{8}$ Whitam had the bad judgment to take on a popular scholarly frame with weak evidence. His surveys were poorly worded, even for their day, his mode of snowball sampling easily criticized, and other researchers failed to reproduce his results (Goode, 1981; Murray, 1991; Omark, 1978).
} 
Most researchers in the deviant social role tradition seem to have been well-meaning, presenting homosexuals and, more broadly, sexual minorities as victims of majority social norms and unjust persecution. Still, the scholars' near-exclusive focus on a more or less seamy social underworld reinforced the stereotype of gay men (and, to a lesser extent, lesbians) as a strange, exotic "other" in contrast to the respectable heterosexuals. Simon and Gagnon's (1967) exhortation to investigate the full range of sexual minorities' social experiences, including those in mainstream workplaces, went largely unheeded. The rise of the gay and lesbian liberation movement would change that and begin to answer Simon and Gagnon's call. The movement also initiated a new scholarly frame to study sexual minorities, one rooted in the movement's ideal of a shared collective identity.

\section{The collective identity frame}

\subsection{A central problem of rights and equality}

Beginning in the late 1980s, research on sexual minorities, in organizations and elsewhere, changed significantly in both volume and character. For the first time, there emerged a true scholarly dialog on the topic, as opposed to the occasional isolated study. For the most part, events outside the academic community drove this shift. Indeed, the 1970s through the early 1990s was a particularly significant period in the history of gay men and lesbian women in the United States (Duberman, 1993; Faderman, 2011; Greenberg, 1988; Taylor \& Whittier, 1992). On the one hand, gay liberation and women's liberation rewrote the sexual landscape of the country. Gay male communities became increasingly visible in large cities (Bailey, 1999; Shilts, 1982), while lesbian feminists built alternative institutions-such as auto repair shops (Weston \& Rofel, 1984) and women's health centers (Simonds, 1996; Ward, 2008)-intended to embody a liberated vision of the future. Legal reforms and protections included the repeal of sodomy laws in more than half the states, the partial lifting of the exclusion of lesbians and gay men from federal employment, and the extension of explicit civil rights protections in several dozen cities. Also, the psychiatric profession agreed in 1974 that homosexuality did not belong on its list of mental illnesses. These advances were matched with some setbacks, however. By the end of the period, the rise of HIV/AIDS brought a sense of devastating crisis and a new source of stigma to the gay community (Shilts, 1987). In parallel, the much-publicized effort to lift the ban on gays and lesbians in the U.S. armed forces withered in the face of political opposition (Herek, Jobe, \& Carney, 1996).

The visibility of the gay rights movement had direct consequences for organizational research on sexual minorities. Now that they had a civil rights movement, sexual minorities could have a place in public life, which included mainstream workplaces. Moreover, the gay rights movement offered a new frame through which its members and other sexual minorities would be studied: as members of a disadvantaged minority group with a shared collective identity. The paradigm caught on with startling rapidity: the language of "identity" is virtually absent from bibliographies of homosexuality studies dating from the early 1970s (Parker, 1971; G.H. Weinberg, 1972), while a review article from 1983 listed several hundred books and articles making use of the term, many emphasizing its collective aspect (Cass, 1984). Discussion of collective identity had rapidly spread throughout scholarship on sexual minorities.

The analogy, sometimes implicit but often explicit as well, was to ethnic identities and the white/black dichotomy that characterized twentieth-century American race relations (Somerville, 2000). The shift in perspective was perhaps most evident in cited references. Unlike the earlier literature, which borrowed references and theoretical insights from the literature on deviant groups such as illegal drug users or juvenile delinquents, researchers increasingly turned to the literature on ethnic identities from the mid- to late 1980s. Not only was the target population typically framed as a similarly disadvantaged minority, but the two identities were thought to share some structural features. Like ethnic identities in the era of eugenics and associated notions of racial purity, sexual identities were seen as a binary in which members of the out-group were marked according to a "one-drop" rule. Just as twentieth-century statutes defined whiteness as the absence of African-American blood, heterosexuality was defined by the absence of homosexual behavior. In both cases, concealment, disclosure, and the problem of "passing" were loaded themes (Brekhus, 1996; Somerville, 2000). In practical terms, treating gay men and lesbians as analogous to African-Americans or women meant that they aspired to equal rights, particularly in the workplace.

The implications of this shift for organizational studies were significant. Conceptualizing sexual minorities as a collective identity made the population suddenly visible within organizations, including public ones, to a degree it had not been in previous frames. The sexologists who developed the medical frame were primarily interested in sexual behavior itself-in documenting the full range of human "abnormality" and thereby delineating the bounds of the "normal" (Chauncey, 1982). A "gay organization" made sense within the social role framework in a way that it did not in the medical frame, but it was necessarily an informal organization such as a social clique or a bar. A homosexual role, like any sexual role, was seen as a private social role that an individual could don and doff at will as he or she moved between worlds. A collective social identity, by contrast, was something more intrinsic to the self, and thus something that carried over into all spheres of an individual's life-including life within organizations. The new consensus on the relative fixity of sexual orientation was seen as a prerequisite (rightly or wrongly) for claiming civil rights for sexual minorities and is evident in the near-complete absence of studies within the collective identity framework on "situational" homosexuality associated with certain sex-segregated organizations, such as prisons, the armed services, and boarding schools (Freedman, 1996; Kunzel, 2002). Consensus on the uniformity of sexual categories was equally broad. Whereas the social role paradigm encompassed a wide variety of nonstandard sexual and gender roles, the 
collective identity frame emphasized instead a starker hetero/homosexual binary (Chauncey, 1994).

At all levels of organizational research, the collective identity paradigm opened up new avenues of research. As members of a collective identity group, sexual minorities were now understood to retain their identity across domains to a degree that players of a social role had not. Research on this population using a collective identity frame fell into roughly three streams: efforts to give visibility to sexual minorities in the workplace, research on the discrimination that sexual minorities suffered within organizations, and studies investigating how sexual minorities create social change. We detail next these three research streams.

\subsection{How can sexual minorities gain more visibility?}

The collective identity approach to sexual minorities lent a new significance to descriptive studies attempting to gauge the size and scope of the gay and lesbian population; related studies attempted to assess the scale of their presence in the world of work. Kinsey announced his 10 percent figure in 1948 with the implicit aim of shaking up straitlaced American sexual mores (Kinsey, 1948); by contrast, estimates made in the last quarter of the century had more political overtones. There were a number of efforts at quantification, some of them specific to organizations. Surveys and other evidence of the late 1970s and 1980s suggested that gays and lesbians constituted anywhere between 4 and 17 percent of the American workforce (Gonsiorek \& Weinrich, 1991). The "second Kinsey" survey conducted in the early 1990s under the auspices of the National Institute for Health put the percentage of self-identified gay men and lesbians in the general U.S. population at 2.8 and 1.4 percent, respectively (Laumann et al., 1994, p. 297); data from the combined General Social Survey and the National Health and Social Life Survey conducted between 1988 and 1996 suggest slightly lower figures, at 1.8 percent of men self-identifying as gay, and 0.6 percent of women (Black, Gates, Sanders, \& Taylor, 2000, p. 142). ${ }^{9}$ This research program aimed to make both the academic and practitioner publics aware that sexual minorities constituted a sizeable portion of the workforce, even though most of them, often by necessity, had to remain closeted.

Complementing the quantitative research on the gay and lesbian population was a parallel body of personal narratives that sought to broadcast the voices of gay and lesbian individuals at work (Boatwright, Gilbert, Forrest, \& Ketzenberger, 1996; Shallenberger, 1992, 1994). By the mid-1990s, gay and lesbian members of organizations ranging from British police forces (Burke, 1993) to corporate boardrooms (Friskopp, 1995; Miller, 1995; Woods \& Lucas, 1993) and higher education (SavinWilliams, 1993) had told their stories in print. To the extent that most of this literature had an agenda beyond visibility, it was to demonstrate that lesbians and gay men

\footnotetext{
${ }^{9}$ The 1990 percentages were heavily contested since they proved much lower than those reported by Kinsey.
}

were "normal" members of mainstream work organizations. Much of this literature presented information about an unfamiliar sexuality in familiar, heterosexual terms in an effort to minimize its stigma and significance (Woods \& Lucas, 1993).

The significance of visibility within the collective identity frame focused particular attention on the themes of minorities' concealment, disclosure, and "coming out." A minority sexual identity is often considered an invisible identity, and the stigma associated with it forces sexual minorities to expend time and effort managing that identity's select expression (Goffman, 1963). Sexual minorities have a number of options for managing their sexual identity in the workplace (King, Mohr, Peddie, Kendra, \& Jones, in press). To avoid potential discrimination, one possibility is to "pass" as heterosexual (Bowen \& Blackmon, 2003; Woods \& Lucas, 1993), a term borrowed from the African-American experience of light-skinned blacks passing as whites (Somerville, 2000). Passing behavior ranges from unintentional to purposeful. Gregory Herek (1996) identifies three primary tactics for passing: fabrication, concealment, and discretion. Fabrication involves deliberately proffering false information about oneself. (Examples of fabrication include inventing fictional heterosexual partners, lesbians taking male friends to office social events, or holding dinner parties to which a same-sex spouse does not attend.) Books and articles on sexual minorities from the 1990s suggested that nearly all respondents had resorted to these or similar strategies at various points in their careers (Hall, 1989; Miller, 1995; Woods \& Lucas, 1993). Concealment occurs when an individual actively prevents others from learning personal information (Herek, 1996). Finally, discretion is the act of avoiding queries or situations in which personal information is or might be disclosed. Persons employing discretion might avoid workplace social functions, temper their appearances or redirect conversations away from leisure time or personal topics (Bilimoria \& Stewart, 2009; Chrobot-Mason, Button, \& DiClementi, 2001). Both concealment and discretion at work amount to forms of social covering (Yoshino, 2006).

Disclosing a sexual identity is the alternative to passing and also involves a number of different tactics. A minimalist approach involves dropping hints and inviting speculation, essentially walking the line between concealment and full disclosure (Clair, Beatty, \& MacLean, 2005; Ward \& Winstanley, 2006; Woods \& Lucas, 1993, p. 176). A second approach, sometimes called normalizing, involves disclosure accompanied by an effort to make a minority and stigmatized sexual identity seem as familiar and nonthreatening as possible. A lesbian employee of a large corporation, for example, reflects that she often makes workplace conversation about her untidy teenage son, or the family's plumbing woes-experiences that her heterosexual colleagues can relate to (Creed \& Scully, 2000, p. 400).

On a broad level, the collective identity frame sees disclosure, or "coming out," as a political act; even regarding it as an obligation to educate colleagues about sexual minorities (Clair et al., 2005). Civil rights claims hinged on disclosure because they derived their legitimacy from the visibility and physical numbers of LGBT 
individuals. Openly gay individuals in positions of responsibility were also seen as important role models for younger members of organizations (Evans \& D'Augelli, 1996). Thus, a considerable body of research has attempted to assess the costs and benefits of concealment versus disclosure. One position holds that being in the closet has a net negative effect on sexual minorities both collectively and individually (Bowen \& Blackmon, 2003; Creed \& Scully, 2000; Creed, 2003; Dejordy, 2008; Ward \& Winstanley, 2003). Indeed, the prevailing view within the literature on stigma suggests that persons who conceal a stigmatized identity experience negative consequences in the form, for example, of lowered organizational commitment, morale, and the cognitive load of concealment (Clair et al., 2005; Day \& Schoenrade, 2000; Escoffier, 1975).

Yet the research findings on the relationship between disclosure of sexual orientation in the workplace, and workrelated attitudes and outcomes proved sometimes contradictory (King, Reilly, \& Hebl, 2008). Some surveys showed that "out" workers enjoyed several advantages: higher job satisfaction, more favorable perceptions of top management, less conflict between work and home, and lower role conflict in general (Day \& Schoenrade, 1997; Griffith \& Hebl, 2002). Likewise, there were some documented disadvantages to remaining closeted. Concealment also made it more likely that gay, lesbian, bisexual, and queer workers would witness sexual prejudice among colleagues, which was shown to cause psychological damage (Willis, 2012) and that they would experience stress and depressive symptoms (Sedlovskaya et al., 2013). Other studies, however, could detect no relationship between disclosure and work attitudes (Croteau, 1996; Driscoll, Kelley, \& Fassinger, 1996). And other scholars even found negative consequences to disclosure: employees that disclosed did not express more commitment to stay at their current workplace (Day \& Schoenrade, 1997) and reported lower pay and lower pay satisfaction (Ellis \& Riggle, 1996). Moreover, disclosure by definition increased vulnerability to workplace sexual orientation discrimination (Badgett, 1996). Still others suggest that a more complex explanation is necessary to account for these divergent findings, one that takes into account such factors as feared reprisals and workplace climate (Ragins, Singh, \& Cornwell, 2007). Subsequent research extended these findings by showing that certain workplace policies-mediated by coworkers' attitudes and reactions-were effective in promoting disclosure and related favorable outcomes for LGBT employees (Button, 2001; Griffith \& Hebl, 2002; Ryan \& Wessel, 2012). As the research on concealment and disclosure indicates, the theme of visibility led naturally to investigation into its correlates: once a previously invisible, stigmatized minority group becomes visible, it opens itself to retaliation on the part of the majority. Thus, research on workplace discrimination followed close on the heels of research on workplace visibility.

\subsection{How does discrimination against sexual minorities operate at work?}

The collective identity frame also gave rise to a body of studies that sought to assess the nature and extent of discrimination against this newly identified interest group. The frame drew particular attention to the many challenges sexual minorities faced at work. As an illustration, researchers documented blatant sexual prejudice manifested in bullying, verbal abuse, and even physical violence at work. Two surveys of lesbian workers in the mid-1980s revealed that large majorities had personally experienced discrimination at work (Levine \& Leonard, 1984; Schneider, 1986); narrative accounts told stories of blackmail, summary termination, and ostracism (Palmer, 1993; Snape, 1995; Woods \& Lucas, 1993). In addition, studies conducted in Austria, Canada, Greece, and the United States have systematically shown that fictional résumés with gay or lesbian markers get significantly lower callback rates than résumés with identical credentials and experience but that do not signal a minority sexual orientation (Adam, 1981; Drydakis, 2009; Hebl, Foster, Mannix, \& Dovidio, 2002; Tilcsik, 2011; Weichselbaumer, 2003). Put otherwise, these researchers provided solid empirical evidence of discrimination against sexual minorities that the gay liberation movement was fighting to eliminate.

Scholars have also tried to move beyond individual experiences of discrimination and study, more broadly, the occupations in which gays and lesbians faced the greatest challenges. An edited volume on Homosexual Issues in the Workplace is a case in point, dividing its occupational section into chapters on the military, the church, primary school teachers, and professional athletes-the fields traditionally most hostile to LGBTs-and emphasizing the barriers to entry, promotion, and overall flourishing (Diamant, 1993). While a small number of studies still considered gay men and lesbians in occupations stereotypically associated with those demographics, such as gay men in professional dance (Bailey \& Oberschneider, 1997) or interior decorating (Matthews \& Hill, 2011), or lesbians in the skilled trades (Weston \& Rofel, 1984), most research efforts in the collective identity tradition examined more mainstream occupational pursuits.

Certain mainstream occupations and professions presented obstacles for sexual minorities of both sexes. For example, jobs that involved contact with young people, particularly K-12 and preschool children, were long identified as particularly problematic for both gay men and lesbians (Olson, 1987). Even in U.S. states that did not explicitly ban sexual minorities from teaching in the public schools, gay and lesbian educators indicated that they felt threatened by stereotypes that associated gay men, and to a lesser extent lesbians, with sexual molestation. Others anticipated moral panic from parents and others about "recruiting" young people into the gay subculture (Burgoon et al., 1989; Ferfolja, 2009; Griffin, 1991; Harbeck, 1991; Kissen, 1996; Olson, 1987). One consequence was particularly high rates of concealment among gay and lesbian $\mathrm{K}-12$ teachers, and continuing underrepresentation in the field as a whole (Baumle, Compton, \& Poston, 2009, p. 164). The general consensus was that higher education proved a comparatively more gay-friendly environment (Savin-Williams, 1993; Sears, 2002), though longitudinal survey data showed that LGBT sociologists who were open about their sexuality, conducted research on LGBT-related 
issues, or were LGBT activists, systematically suffered negative career consequences (Taylor \& Raeburn, 1995).

The military was another challenging workplace for sexual minorities, particularly in the United States forces. Homosexuality was grounds for dismissal until 2010, modified only slightly by the passage of the "Don't Ask, Don't Tell" policy in 1993, which prohibited members of the military from inquiring as to other members' sexual orientation (Herek, 1996; Shilts, 1993). Despite policy changes, lesbian, gay, and bisexual service members continue to experience incidents of victimization in the military (Burks, 2011). Even in nations that did not formally ban gays and lesbians from the armed forces, such as Israel after 1993 (Belkin \& Levitt, 2001), sexual minorities still frequently suffered a hostile workplace climate.

A related body of research explores the intersection between strongly gendered jobs and sexual orientation. Workplaces with strong masculine cultures, such as the skilled trades, police, and fire departments, were shown to present different obstacles to gay and lesbian workers, respectively (Embrick, Walther, \& Wickens, 2007). For instance, the aggressive masculinity of police and fire forces hampered an openly gay officer's efforts to earn trust and respect from his peers and made many men reluctant to disclose their sexual orientation (Bernstein \& Kostelac, 2002; Burke, 1993; Miller, Forest, \& Jurik, 2003). It did not follow, though, that lesbian officers and firefighters fit in effortlessly: many endured regular homophobic treatment and sexual harassment from their coworkers (Burke, 1993; Chetkovich, 1997; Lewis \& Pitts, 2011; Martin, 1980; Rumens \& Broomfield, 2012; Ward \& Winstanley, 2006).

Slightly different dynamics were at play in traditionally female professions such as nursing, social work, librarianship, and flight attendants. These settings lacked much of the overt homophobia of the police, fire, and skilled trades, allowing lesbian women to go largely unmarked (Hochschild, 1983; Lewis, 2010). Men of any sexual orientation, however, often faced a presumption of homosexuality in these professions that complicated their interpersonal workplace relations (Harding, 2007; Williams, 2013; Zurlinden, 1996). Again, these studies focused on discrimination at work as the main questions to explore with respect to sexual minorities.

An important subcategory of discrimination research was the effort to assess its impact in material terms. The ongoing effort to document the extent and nature of the socioeconomic gap between gays and lesbians and their straight counterparts-colloquially known as the "gay gap" (a pun on pay gap)-was another line of research that both drew on and reinforced the notion that gays and lesbians constituted a defined interest group. Lee Badgett (1995, 2002) discredited the then-widely held misconception that gays and lesbians enjoyed higher average income levels than the population as a whole. ${ }^{10}$ Research extending this

\footnotetext{
10 Previous analyses of gay men and lesbians' income levels had been based on the subscription lists of gay or lesbian publications which, like subscription lists for most magazines, included disproportionate numbers of educated and well-off readers.
}

line of inquiry showed that gay men in particular experienced a wage penalty, though the data was more equivocal for lesbians (Berg \& Lien, 2002; Black, Makar, Sanders, \& Taylor, 2003; Blandford, 2003). Labor market "demand-side" explanations posited that openly gay men and lesbians would be more likely to be hired into the more tolerant (and usually lower-paying) occupations (Badgett, 1995). "Supply-side" explanations observed that sexual minorities' own willingness to sacrifice higher pay or benefits for a supportive organization or work group could have the same sorting effect (Escoffier, 1975; Klawitter \& Flatt, 1998). Similarly, a number of studies found that human services and other occupations commonly associated with nonprofit organizations had disproportionate numbers of LGBT employees (Lewis, 2010; Ng, Schweitzer, \& Lyons, 2012). A recent study suggesting that LGBT people are more likely than heterosexuals to prefer public and nonprofit sector employment lend support to the self-sorting hypothesis (Lewis \& Ng, 2013).

Finally, another strain of discrimination research investigated its interrelationship with broader cultural dynamics, such as legal frameworks, workplace policies, work group composition, and other contextual factors (Chuang, Church, \& Ophir, 2011; Creed, Scully, \& Austin, 2002; Day \& Greene, 2008; Negro, Carroll, \& Perreti, 2013; Ragins \& Cornwell, 2001; Tilcsik, 2011). For instance, the level of discrimination against gay men in the United States was shown to reflect in part regional differences in attitudes and antidiscrimination laws (Tilcsik, 2011). Also, Belle Rose Ragins and John M. Cornwell (Ragins \& Cornwell, $2001)$ used a large survey $(N=768)$ to develop a model of the antecedents and consequences of perceived workplace sexual orientation discrimination that suggested some surprising relationships. Levels of compensation and of perceived discrimination, for example, showed no relationship. As the concept of the "lavender ceiling" (Friskopp, 1995) suggested, however, occupational mobility and perceived discrimination were closely linked, possibly because the grooming, mentoring, and networking involved in promotion required a degree of socialization and "fitting in" that many sexual minorities struggled with (Hebl, Tonidandel, \& Ruggs, 2012). Another surprising finding was that lesbian and gay workers who worked in primarily heterosexual work groups earned more than those with a significant number of gay coworkers, lending support to past research suggesting that gay workers chose or were tracked into lower-paying "gay ghettos" (Levine, 1979). All these studies suggest a layered, multi-level story of discrimination that can include, for instance, a combination of institutional, occupational, and organizational dynamics.

Accordingly, a revised research agenda aimed at uncovering the hidden challenges faced by lesbian, gay, and bisexual employees in a supposedly more open and inclusive era. Rather than simply documenting the material and psychological damage suffered by sexual minorities in mainstream organizations, researchers sought to identify covert manifestations of heterosexism, even on the part of individuals who believed themselves to be unprejudiced. One field study, for example, showed that 
though hiring rates for openly gay applicants were comparable with the field as a whole, employers spoke less, had briefer interactions, and engaged in more nonverbal discrimination with sexual minorities than with heterosexual applicants (Hebl et al., 2002). Others document a new "homonormativity" that tolerates disclosure of a minority sexual identity but punishes those who chose to more fully enact their sexual identity at work (Williams, Giuffre, \& Dellinger, 2009).

As suggested above, the collective identity frame opened up a flurry of new venues for organizational research on sexual minorities. Once the visibility of the minority group had been established and the discrimination it suffered discussed, an additional stream of research sought to understand how this situation could change. This third stream, discussed next, investigates how sexual minorities can actively create social change.

\subsection{How can sexual minorities create social change?}

At the organizational level of analysis, the impact of the collective identity paradigm was to make intelligible the notion of a public, formally constituted gay organization, as opposed to the more or less covert informal organizations (e.g., bars, bathhouses, tearooms) where "sexual deviants" congregated. In practice this nearly always meant social change organizations, as gay or lesbian business organizations were comparatively few and small in size, such as the auto repair shop owned and staffed by lesbians documented by Weston and Rofel (1984). Accordingly, the research on LGBT organizations drew extensively on social movement scholarship between the late 1980s and the present (Armstrong, 2002; Fassin, 2010; Walker, 2012).

One stream of research explored how gay and lesbian social change organizations, like other New Social Movement (NSM) organizations (Breines, 1982), succeeded or failed in creating change. In particular, the volatility and instability of gay, lesbian, and other NSM organizations proved a common theme. Frequently, such studies concluded that these organizations eventually self-destructed: members sacrificed "organizational maintenance" for fidelity to anti-establishment ideals (Baker, 1982; Gamson, 1995; Gould, 2009; Weston \& Rofel, 1984). But organizational demise or drift was not always self-induced. Joshua Gamson (1996) has shown how two New York gay \& lesbian film festivals found their ties to the LGBT community compromised by the need to seek support and legitimacy outside that community. Government and private foundation sources of funding required evidence that the festivals served a population beyond their white, mainly middle-class base; organizers also felt compelled to cater to the heterosexual art-house film constituency. Similarly, Jane Ward showed that the pursuit of funding and other forms of organizational legitimacy drove a wedge between mission and practice for three Los Angeles LGBT nonprofit organizations (Ward, 2008).

Other scholars looked at the tension between such organizations' common conflicting goals, namely organizational legitimacy on the one hand, and on the other a perceived need to resort to unconventional or confrontational tactics to achieve change. Alongside a case study of an environmental group, Kimberly Elsbach and Robert Sutton (1992) conducted a case study of AIDS Coalition to Unleash Power (ACT UP), founded in 1987, as an example of an organization that deployed illegitimate, and sometimes even illegal, tactics, to raise public awareness of its demands on both government and private corporationsin this case, increasing government funds for AIDS research, education and treatment; opening access to experimental drugs; lowering treatment costs; and allowing people with AIDS to participate in decisions on drug trials. A similar study on institutional resistance tactics showed how, in 1991, a boycott and negative publicity organized by the National Gay \& Lesbian Task Force led stockholders to force Cracker Barrel restaurant to rescind a decision to dismiss all gay and lesbian employees (King \& Soule, 2007). In that sense, gay and lesbian organizations proved exemplars of the often-difficult decisions social change organizations make in service to their causes.

Another related research stream considers gay and lesbian individuals and networks, rather than established social movement organizations, as change-agents within organizations. Nicole Raeburn's (2004) study of gay and lesbian workplace activists at Fortune 1000 companies conceptualized the campaign for domestic partner benefits as a social movement taking place within organizations, thereby making sense of the fact that employers often offered these benefits in advance of state or federal legislation that forced their hands. Other scholars drew attention to the ways that individual organizational change-agents frame issues and capitalize on opportunities within an organization's internal polity, sometimes by even forming internal LGBT employees groups (Ghosh, 2012; Githens \& Aragon, 2009; Scully \& Segal, 2002). For example, Douglas Creed and Maureen Scully (2000) show how workplace encounters in which LGBT workers purposefully deploy their social identities can become instances of "micromobilization" which function to challenge and reform existing organizational cultures and structures by a process of accretion. Subsequent empirical work on two mainline Protestant denominations shows how LGBT clergy selectively deployed voice and silence to promote institutional change while framing their actions as enactments of existing institutional values and beliefs (Creed, 2003; Creed, Dejordy, \& Lok, 2010).

Over time, the limitations of the collective identity frame became increasingly apparent. One objection was essentially political. John D'Emilio (1983) offered an early critique of the "minority group" agenda (strongly coupled to the collective identity frame), charging that it reinforces existing hierarchies. "It leaves today's youth-tomorrow's lesbians and gay men-to internalize heterosexist models that it can take a lifetime to expunge" (1983, p. 138). Others criticized the collective identity frame for implying that lesbians, gay men, bisexuals, and other sexual minorities share a single social identity. Moreover, the collective identity frame presupposes a hetero/homosexual binary that fails to capture the variety of sexual expressions. Bisexual employees, for example, claim they face hostility and discrimination for being "unstable" or "unreliable" not only from straight colleagues but from gay ones as well (Köllen, 2013). The frame also rendered 
invisible individuals who participated in same-sex sexual activities but did not identify as sexual minorities. There is little place in this frame, for example, for the conservative, married father of seven who frequented the tearooms studied by Humphreys (1975).

While an idealized view of a cohesive identity shared by sexual minorities helped cement the collective identity frame's research agenda, such a view also left out much of the texture and singularities of diverse sexual minorities. This relative loss calls for more in-depth research on the varied and distinct experiences of sexual minorities per se. The social distinctiveness frame that we describe next answers in part this call.

\section{The social distinctiveness frame}

\subsection{A central problem of understanding distinctiveness}

The defining feature of organizational research on sexual minorities employing a distinctiveness frame is the assumption that the population under study is one whose behavior or experiences are distinct and differ in significant ways from those of women or ethnic groups. In the same way that some feminist scholars have posited a certain uniqueness to women's behavior or experiences (Chodorow, 1978; Gilligan, 1982), a social distinctiveness frame assumes a certain incommensurability and therefore uniqueness to sexual minorities' behavior and experiences. The implication is that sexual orientation or gender identity is a category that might share some features with a range of other categories, but should not be overly identified with race or gender. This frame allows for the possibility that particular sexual minorities are distinct from other outside groups (for instance, African-Americans), and also that there are distinctive sub-groups within the broader category of sexual minorities. In that sense, the notion of distinctiveness operates at multiple levels: for example, between lesbian and straight women, within sub-groups of lesbian woman, and more.

While early scholarship (adopting a medical frame) suggested that a gay or lesbian individual's abnormality could (mostly negatively) infuse all aspects of his/her life, the more recent scholarship reliant on a distinctiveness frame assumes that an individual's gay or lesbian inclination can infuse all aspects of his/her life, but remains mostly neutral, if not positive, on the consequences of such infusion. A research agenda emphasizing social distinctiveness also foregrounds the ways in which a nontraditional sexual orientation might convey unique skills and advantages at both the individual and organizational level-as opposed to a minority group paradigm (associated with the collective identity frame) which generally emphasizes obstacles and challenges.

Several research areas lend support to the notion of LGBT distinctiveness. One is the growing consensus that sexual prejudice, sometimes called homophobia or heterosexism, is qualitatively different from racism or sexism. Heterosexism is defined as "an ideological system that denies, denigrates, and stigmatizes any nonheterosexual form of behavior, relationship, or community" (Herek \& McLemore, 2013). Though there is evidence that heterosexism springs from the same social, cultural, and political foundations as racism and sexism [they can be, for example, highly correlated (Henley \& Pincus, 1978) and share some of the same predictors (Herek, 1984)], there are important differences. Elizabeth Young-Bruehl (1996), for example, suggests that heterosexism is more complex than the three other principal prejudices (i.e., racism, sexism, and antiSemitism). For one thing, there appears to be no counterpart to homophobia-fear of homosexuals grounded in heterosexuals' fear that they are or may become gay (M.S. Weinberg, 1972)-in racism or sexism (Ragins, Cornwell, \& Miller, 2003). Secondly, homosexuality is sometimes thought to carry a "courtesy stigma" (namely, the stigma attached to those who are merely associated with a stigmatized person) (Goffman, 1963, pp. 30-31), tainting friends and family of gays and lesbians in a way that some suggest has no parallel in race or gender (Herek \& Capitanio, 1999). Finally, the focus, mobilization, and intensity of religiously based heterosexism is also unique; race and gender are not viewed as immoral life choices that violate religious beliefs (Barton, 2012). Just as heterosexism is categorically different from racism or sexism, it follows that the lived experience and identity formation of sexual minorities should differ as well.

A second line of research that supports the use of a distinctiveness frame is the (still comparatively scant) contemporary inquiry into the biological and social pathways that determine sexual orientation. For the most part, the work of physiologists, geneticists, and evolutionary biologists have had relatively little impact on organizational research in sexual minorities, though biological explanations of sexual orientation proliferate, shorn of the pejorative connotations they conveyed within the medical abnormality frame (Hamer, Hu, Magnuson, Hu, \& Pattatucci, 1993; Hershberger, 1997; McGuire, 1995; Parker \& De Cecco, 1995; Risman \& Schwartz, 1988). In the ten years prior to 2010, the average annual number of published articles on possible biological determinants exceeded two dozen in PubMed alone (Whitehead, 2011). Yet meta-analyses regularly conclude that "the evidence for genetic and/or hormonal effects on same-sex orientation is inconclusive at best" (Bearman \& Brückner, 2002, p. 1180). ${ }^{11}$ In fact, not only does biological research rarely intersect with LGBT organizational research, but organizational scholars-like the majority of social scientistsrarely even take up empirical research that considers individual variation in sexual orientation, focusing instead on an ethnographic approach that emphasizes variation in the social expression of sexuality (Bearman \& Brückner, 2002; Risman \& Schwartz, 1988). Still, the syntheses of social and biological sciences that do exist, such as that of Peter Bearman and Hannah Brückner (2002), finds evidence that individual variation in sexual orientation among adolescents may indeed have roots in specific socialization experiences. The study suggests that pattern of concordance (similarity across pairs) of same-sex

\footnotetext{
${ }^{11}$ For a similar conclusion on the inconclusiveness of the genetically based evidence of same-sex attraction see also Stein (1999) and Whitehead (2011).
} 
preference for sibling pairs depends in part on social context. For instance, male adolescents who have a female twin are more likely to report same-sex attraction than any other group (such as same-sex twins) (p. 1194). Thus, a particular social context might combine with a genetic predisposition to activate the expression of a minority sexual identity.

Finally, the relatively recent revival of empirical research on LGBT sex work and other stigmatized occupations and organizational settings suggests that the strictures of the collective identity frame are loosening, such that there is revived interest in the distinctiveness of sub-groups within the broader "sexual minority" category. Seamy underworld sites like prostitution rings or stripdance clubs were typical research sites of the deviant sexuality frame, but, as Donna Penn (1995) has observed with regard to the eclipse of prison sexuality research during the gay rights movement, evidence from such sites "has been shunted aside ... with arguments that it does not represent the lives of the 'normal,' 'well-adjusted,' 'average' lesbians" (and gay men) that most research spotlighted" (Penn, 1995, p. 25). To be sure, some studies find that male sex workers and their male clients have much in common with their female-male counterparts (Padilla, 2007; Smith, Grov, Seal, \& McCall, 2013), but others turn up differences. For instance, (often gay) male escorts' behavior differs markedly from their female counterparts: as an example, males who advertise masculine norms (e.g., being a top) charge higher prices for their services than those advertising less masculine behavior (being a bottom) (Logan, 2010). This suggests that distinct dynamics might be at play within this community. These studies suggest a need to better probe into and understand the oftendifferent ways that sexual minorities operate within the broader society.

Taken together, the above research developments on sexual minorities' distinctiveness (compared to other social groups or even other sexual minority groups) have triggered a revival of organizational scholarship in at least two main domains. The first concerns itself with the distinctiveness of sexual minority workers. The second domain examines the distinctiveness of formal organizations populated in majority by sexual minorities. We detailed next these two areas of research.

\subsection{What makes sexual minority workers distinct from other workers?}

One key feature of literature within the distinctiveness paradigm is that it is open to the ways in which a worker with a nontraditional sexual orientation might convey skills and advantages that distinguish him or her from workers claiming a majority sexual orientation. Some studies suggest that these traits and abilities can be leveraged both by workers and organizations to achieve higher performance. The implication, too, is that if LGBT distinctiveness can in some contexts be an asset, it might also be a liability. Regardless, research treating the sexual orientation of workers within a frame that aims to investigate their distinctiveness requires scholars to go beyond the collective identity frame and focus on what
LGBT workers bring to the workplace, rather than what they are missing out on.

For example, researchers might test and extend Kirk Snyder's (2006) suggestion, based on over 3000 interviews with Fortune 500 professionals, that gay men and lesbians might manage differently than their straight counterparts, and they may be better in some respects. Living with a sense of differentness, he posits, tends to give sexual minorities a number of learned skills that have value in the workforce, among them adaptability, creative problem solving, and intuitive communication. Life experience as an outsider, he claims, leads gay managers to regard each worker as a unique individual-a distinct advantage in retaining talent, particularly in knowledge industries in which employees are mobile and highly educated. Snyder suggests that the subordinates of gay managers have significantly higher levels of job engagement, job satisfaction, and workplace morale. The possibility that LGBT individuals bring distinctive qualities or expertise (also unlike those brought by other minorities) to organizations warrants further research.

More empirically grounded studies in network sociology-particularly the dyads and triads of workplace relationships-may have a particularly easy time in shrugging off the minority group analogy. Research on workplace friendships, for example, highlights the distinctive ways in which sexual orientation shapes the way individuals give and seek support at work (Huffman, Watrous-Rodriguez, \& King, 2008). There is an established body of research, for example, on the centrality of friendship to LGBT lives (in contrast to the family ties that tend to define ethnic groups) (Galupo, 2007; Nardi, 1999; Weeks, Heaphy, \& Donovan, 2001), yet some research suggests that at the workplace, LGBT workers prefer to befriend heterosexual colleagues (Rumens, 2010, 2011, 2012). Stereotypes, such as those that depict gay men and heterosexual women as "naturally" more understanding and affectionate than straight men, can influence the nature of ties between members of these groups. Though some respondents indicated that such stereotypes reinforced the supportive nature of workplace friendships between gay men and straight women, others indicated that they experienced the stereotype as restrictive (Rumens, 2012). These insights only begin to tap the likely dynamics of sexual orientation in workplace friendships and other workplace behavior.

There are also a few recent contributions that give a sense of what it might look like to base an occupational research agenda on the distinctive contributions and experiences of sexual minorities. Scholars have long noted the existence of lesbian and gay occupational concentrations (Ellis, 1897; Hewitt, 1995), but Allan Bérubé was perhaps the first one to genuinely ask from an empirical perspective "What's a queer job?" (2011, p. 259). From blue-collar craft jobs and commercial truck driving to army mechanics and gymnastic teachers (for lesbians), and professional dancers and church organists to sailors and interior designers (for gay men), many scholars have noted the strikingly high concentration of lesbian and gay workers in certain occupations (Badgett, 1995; Bailey \& Oberschneider, 1997; Bérubé, 2011; Hetherington \& Orzek, 1989; Whitam, 1986). One of the first studies to report 
national estimates of gay and lesbian occupational concentration used U.S. Census data for same-sex partners in 33 of the largest professions and showed that gay men and lesbians were "concentrated in the [professional] fields that focus on creativity, psychology/counseling, and law/social work" (Baumle et al., 2009, p. 168). The reasons for such concentrations have until now remained hard to explain.

Recent scholarship adopting a distinctiveness frame suggests however that such concentrations might be in part linked to the features of the jobs themselves (Tilcsik, Anteby, \& Knight, 2014). Drawing on Goffman's (1963) classic insight that a principal challenge for individuals with concealable stigma (like LGBT individuals) is to manage information about their stigmatized status in social interactions, this research shows that the need for stigma management-both in the workplace and beyond-might have important consequences for occupational segregation. In a study using the American Community Survey (ACS) (a nationally representative sample of nearly five million people allowing to systematically identify individuals living with a same-sex partner) and the National Longitudinal Study of Adolescent Health (encompassing respondents between the ages of 26 and 31 and providing several indicators of sexual orientation independent of partnered status), András Tilcsik, Michel Anteby, and Carly Knight show that gay and lesbian workers are overrepresented in occupations that share certain characteristics. Their analysis suggests that gay men and lesbians are attracted to and/or perform well in occupations that provide a high level of "independence" and/or require a high level of "social perceptiveness." Independence is defined as the ability to work and make decisions autonomously and social perceptiveness as the awareness at work of others' emotions and accurate anticipation of their reactions. Indeed, jobs providing relatively high independence (e.g., massage therapists or web developers) allows their members to manage information about their stigmatized status more effectively in the workplace, while also mitigating the risks associated with disclosure. Social perceptiveness, in turn, is essential for gay and lesbian individuals' social adaptation to everyday situations. Addressing the dilemma of disclosure versus concealment on an ongoing basis requires a sensitive reading and accurate anticipation of others' reactions, which in turn are valued abilities in jobs that require a high degree of social perceptiveness (e.g., social workers and probation officers). These results suggest that a distinctiveness frame can parsimoniously explain a large set of seemingly haphazard employment patterns across the occupational spectrum.

The fluidity of a minority sexual identity-a dimension of social identity far more dominant in sexual orientation than in racial or gendered identities-is also evident in some recent occupational research. ${ }^{12}$ By fluidity, we refer to the dimension of change over time in identities, highlighting the fact that sexual desires and identities can evolve, and can thereby result in a lack of alignment

\footnotetext{
12 Both Michael Storms (1980) and Fritz Klein (1993) raised scholars' awareness of the need to better capture the fluidity and complexity of sexual identities by offering alternate scales to those used by Kinsey (1948).
}

between desire and behavior, and behavior and identity (Diamond, 2008). The renewal of interest in LGBT sex work and certain same-sex occupations has also revived interest in the old notion of situational homosexuality, which shows some affinities with the new concept of fluidity in sexual orientation. Jeffrey Escoffier (2003), for example, points out that the phenomenon of "gay-for-pay"-selfidentified straight men who create credible sexual performances in gay porn films-is an extreme example of situational homosexuality, in which straight men draw on literal scripts, scenery and actors to create credible homosexual performance. Presumably, he concludes, such dynamics are at work in other situations. Bernadette Barton (2006) nods to the dimension of change over time in sexual orientations in her discussion of queer desire among female strippers. Well over half of her interviewees identify as lesbians, she surmises, thanks to selection pressures: women who enter the field uninterested in men may find the work less emotionally draining. But she also notes features of the occupation that permit and even reward same-sex sexual behavior. Dancers form close friendships, the atmosphere of sexual freedom encourages some to experiment, and frequent exposure to boorish male customers makes intimacy with women an attractive alternative (Barton, 2006). All of these studies foreground the extent to which sexual orientation can be subject to change over time and in response to context; dimensions of identity marginalized by the collective identity frame.

Overall, what the social distinctiveness frame brings to organizational research on select sexual minorities is a renewed awareness that their unique workplace experiences need to be further examined both in relation to sexual majorities and also other sexual minorities. Indeed, many dimensions of their experiences (such as gender fluidity or acquired skillsets) might be unique. For example, a recent study on the occupational attainment of lesbians and gay men explicitly focuses on the significance of the age at which an individual became aware of his or her nontraditional sexual orientation-a temporal dimension of identity that has no direct counterpart in race or gender (Ueno, PeñaTalamantes, \& Roach, 2013). Also, recent research on black gay men documents the diverse and unique narrative strategies they employ to navigate their racial and sexual identities (Hunter, 2010). As the list of sexual orientations and gender expressions grows from gay and lesbian to LGBTQQI and beyond (lesbian, gay, bisexual, transgender, queer, questioning, and intersex), the distinctiveness of these sub-populations begs to be better understood. ${ }^{13} \mathrm{~A}$ similar distinctiveness approach applies also to organizations in majority populated by sexual minorities.

\subsection{What makes organizations populated mainly by sexual minorities distinctive?}

In the past, some LGBT organizations were considered as settings for research questions on a variety of topics-for

\footnotetext{
${ }^{13}$ Intersex is defined as a variation in sex characteristics-chromosomes, gonads, and genitals-that do not allow an individual to be distinctly identified as male or female.
} 
example, the question of organizational legitimacy in Bryant Hudson and Gerardo Okhuysen's (2009) study of gay bathhouses - but the specificity of the LGBT organization was rarely noticed or discussed. By contrast, the notion of a distinctively gay organizational form plays a key explanatory role in Elizabeth Armstrong's (2002) account of the strength and durability of the gay rights movement-arguably the most successful of the New Social Movements begun in the 1960s and 1970s. Armstrong's cultural-institutional analysis argues that it was by embracing distinctiveness and internal diversity that the movement has flourished decades after other New Left identity politics movements foundered and all but died out. As Armstrong explains, the logic of identity politics once served an essential purpose: it allowed lesbian and gay organizations to break out of the doublebind of organizing in the homophile era, in which activists' pursuit of legitimacy and respectability were stymied by the secrecy necessary to claim that respectability. Yet, Armstrong asks, why and how did the gay rights movement avoid the rancorous infighting and fragmentation to which other identity politics movements have succumbed? In answer, Armstrong points to the emergence of a novel organizational form, which she calls the "Gay + 1" organization: the Gay/Lesbian Quilters, for example, or the Safe Sex Leather Sluts. This new organizational form combines an emphasis on nontraditional sexual identity and identity building (the "Gay" part) with specific tasks or functions (the " +1 " part) that allowed the movement as a whole to expand and mutate so to accommodate a range of agendas and identity expressions. While it looked to the casual observer as if the movement had fragmented, Armstrong suggests that it was merely the manifestation of a new organizational logic-unity in diversity-that was the counterintuitive source of the movement's resilience. This distinctive organizational ability to accommodate internal diversity suggests that organizations populated by sexual minorities might exhibit an unusually high degree of flexibility in organizational identity.

There are also a number of studies suggesting that queer work organizations often intentionally mix the realms of intimacy and work, possibly as a way of challenging heteronormativity. Deborah Gould's (2009) study of the AIDS Coalition to Unleash Power (ACT-UP) argues, for example, that the sexual orientation of the majority of organization's members gave the organization its distinct form. ACT-UP, she shows, explicitly rejected the notion that the realm of intimacy-emotions in particularhad no place in an organization with serious political goals. Not only did the organization energize its operations by drawing on the fear and frustration surrounding HIV/AIDS in the years before effective therapies, but it also deliberately blurred the distinction between socializing and social change: meetings were an opportunity for cruising and flirting as well as planning strategy. Similar dynamics are at work in strip clubs (Barton, 2006), a shortorder restaurant kitchen (Lerum, 2004), and the Parade Department at a theme park (Orzechowicz, 2010): organizations that seem to allow a relatively high degree of play with gendered and sexual presentations of self. But even in more traditional settings, new organizational forms experiment with the possibility of bringing nonwork identities into the workplace as part of the culture (Ramarajan \& Reid, 2013). For instance, Peter Fleming and Andrew Sturdy (2011) describe an Australian call center in which management overturns the traditional expectation that employees develop a homogenized, organizational persona at work. Rather, employees were encouraged to display and even celebrate their non-work identities-particularly minority sexual orientations-in the name of freedom, equality, and authenticity (p. 188).

Whether the embrace of "identity flexibility" and "intimacy" are distinct attributes of LGBT organizations remains to be more fully confirmed, but a distinctiveness frame draws our attention to the possibility of such distinct and common features across a range of LGBT organizations. In the same manner that feminist organizations might have distinct features (Calás \& Smircich, 2006; Ferree \& Martin, 1995; Martin, Knopoff, \& Beckman, 1998), LGBT organizations-or simply organizations with a critical mass of LGBT members-might exhibit some invariants that unite them across settings and industries. Moreover, little research has been conducted to date on the relative distinctiveness of organizations populated mainly by certain subgroups, such as lesbians versus gay men. Yet we might expect that organizations dominated by subgroups of sexual minorities will exhibit distinct attributes uniquely suited to certain contexts.

Further research should, for instance, ask whether these distinctive features prove particularly valuable in certain contexts or industries, possibly explaining the concentration of LGBT organizations in these settings. For example, the identity flexibility that LGBT organizations seem to exhibit might prove particularly beneficial in crosscultural settings in which accommodating diverse cultural identities often proves challenging. Researchers might therefore want to examine whether LGBT organizations are particularly adept at navigating across national cultures. By contrast, the assumed distinctiveness of LGBT organizations can carry disadvantages. For instance, assuming LGBT organizations easily accommodate diverse identities, does such an embrace also translate into a dilution of the combined organizational identity? If so, might we expect, for example, lower levels of organizational identification among members of LGBT organizations versus non-LGBT organizations? If an LGBT organization accepts many identities can it still it stand for one in particular? If not, what might be the identification implications for its members? Such questions illustrate the many ways in which scholars might adopt a distinctiveness frame to explore new questions with respect to LGBT organizational research.

\section{Conclusion and future directions}

The four main scholarly frames that we presented above offer a way to organize and revisit organizational research on sexual minorities. They point to key implicit assumptions in the field and offer a language to make sense of the shifting landscape of LGBT organizational research. Importantly, the frames also alert us to our own potential 
biases and blind spots in our research pursuits. Indeed, how micro-interactions at work come to aggregate and shape or reflect broader social structures is a topic of great interest to organizational scholars. But scholars are also workers and need to deploy the same analytical apparatus that they used on "others" to themselves. Our work has no reason to be outside the realm of scholarly inquiry. As such, we are not different from other populations that we often depict as being embedded in organizational and field-level dynamics. ${ }^{14}$

When interacting with others (e.g., by reading other people's work) and conducting studies, researchers both shape their field of inquiry and reflect a broader ethos. That ethos is strongly influenced by the dominant frame(s) used at any given time. Like managers making strategic decisions (Kaplan, 2008), researchers view their world through consequential frames. By making such frames apparent, our intent is to make more salient the embedded "traps" we might unknowingly fall into. Bringing a sharper awareness of the dominant frame in use (for instance, a collective identity versus a deviant social role frame) can help us be more reflexive about the questions that might implicitly be driving our research as well as those we are not asking.

We are well aware, however, that researchers often juggle multiple frames in their own projects and that the temporal boundaries between frames are not always as clearly delineated as we have suggested. Moreover, it is worth repeating that the timeline presented here is a schema of scholarly paradigms, and makes no claims about the emergence of such perspectives and worldviews outside of the academic realm. In that sense, the idea of a "sudden" emergence of the collective identity frame should be viewed with caution, for its suddenness was confined to the realm of organizational studies, not the wider cultural milieu where it had long roots. Our hope, however, in fleshing out these main scholarly frames is to characterize them and encourage other scholars-whether or not explicitly studying sexual minorities-to explore them and their effects in directing the course of their research, rather than to try to precisely date them.

For scholars studying sexual minorities, we hope to have highlighted the new research opportunities that shifting frames might entail. Past research on sexual minorities at work have often called for producing "more" studies on the topic, for example, by encouraging other (mainstream) scholars to pay more attention to this areas of research (Creed, 2006; Githens, 2009; Williams \& Giuffre, 2011) and by expanding the geographical scope of inquiry into sexual minorities to non-western countries (Ozturk, 2011). More such research in those directions is clearly needed, but future research should also explore and allow for the use of multiple scholarly frames when examining sexual minorities. As an illustration, in the same way that research has shown men and women experience sexual harassment at work quite differently (Berdahl, Magley, \& Waldo, 1996; Waldo, Berdahl, \& Fitzgerald,

\footnotetext{
${ }^{14}$ See Anteby (2013) for a recent example of an inquiry into organizational vs. field-wide academic tensions.
}

1998), a social distinctiveness frame might suggest digging deeper into sexual minorities' experiences of such harassment to document its potential distinctness and see how it compares to other experiences. While much of the research on harassment tends to be conducted in the collective identity frame (namely, highlighting discrimination), a frame shift in this instance would refocus attention and efforts to another part of the harassment puzzle: its potentially distinct quality depending on one's sexual orientation. Put differently, exploring and critically interrogating alternate frames used to address an issue might be as beneficial as expanding the number of studies (in a given frame) on that same issue.

An awareness of the frames in which sexual minorities have been studied could also direct attention to the study of certain other populations, particularly sexual majorities. For instance, a scholarly approach that aims to illuminate and enumerate the distinctive qualities, experiences, and behaviors of sexual minorities in the workplace necessarily draws critical attention to the more elusive sexual majority. Scholars from across the disciplines have recently observed that heterosexuality is as constructed as a marked counterpart to homosexuality (Valocchi, 2005; Williams et al., 2009). But majority sexualities in organizations have received even less sustained, focused attention than their minority counterparts. ${ }^{15}$ An analytical frame that regards minority sexual orientations as distinctive might make it possible to see the distinctive invariant features of heterosexuality in organizations in much the same way that researchers have begun to uncover the ways in which whiteness (Brander Rasmussen, 2001; Dyer, 1997; Macalpine \& Marsh, 2005), maleness (Adams, 2005), and other forms of normativity are constructed. Like any kind of normativity-defined as "conventional forms of association, belonging, and identification” (Halberstam, 2005, p. 4)heterosexuality is unmarked and as such deflects attention away from itself, making it difficult to see. Also, an analytical frame that regards sexual majorities as enacting distinct social roles might uncover a variety of novel ways by which majority sexualities enact their roles. For instance, the idealized heterosexual male "role" at work might mask consequential varied forms of enactment (Ely \& Meyerson, 2010; Reid, 2011). These examples are only some of the many ways organizational scholars might want to try applying and even expanding the repertoire of frames we identified and see how these frames might modify their own research agendas.

Organizational research on sexual minorities, and the contrasted frames that scholars have adopted to pursue such research, can teach us more than the experiences of sexual minorities in the workplace. This body of research can teach us how often implicit scholarly frames shape research agendas and dictate the key questions to be answered over extended periods of time. Certain research sites, topics, and approaches come into focus at the center of the frame, while others are marginalized or even

\footnotetext{
15 One reason sexuality, more broadly, is rarely explored in organizations is perhaps a fear of intimacy in organizational life represented in the ideal of the sanitized workplace (Schultz, 2003; Zelizer, 2009).
} 
rendered invisible. Moreover, the nature of the frameshere, the notion that the field's central problem entails defining the sexual minority under study (Hekma, 2007)obscures potentially vast and rich areas of inquiry into sexual orientations in the workplace, both minority and majority. Yet organizational scholarship on sexual orientation in all its flavors-including dominant ones-is only starting to gain traction. Ultimately, what research on sexual minorities will teach us is to recognize the way we approach our inquiries both enables and constrains our ability to see a social phenomenon and ask pertinent questions: a lesson with implications both for minority and majority populations in organizations.

\section{Acknowledgments}

We are extremely grateful to Art Brief and Barry Staw for giving us the opportunity to pursue this project and for pushing us to sharpen our argument. We also thank Douglas Creed, Robin Ely, Giacomo Negro, Lakshmi Ramarajan, and András Tilcsik for their comments on this article.

\section{References}

Abrams, A. (1918). Homosexuality-A military menace. Medical Review of Reviews, 24(9), 528-529.

Achilles, N. (1967). The development of the homosexual bar as an institution. In J. H. Gagnon \& W. Simon (Eds.), Sexual deviance (pp. 228-244). New York: Harper \& Row.

Adam, B. D. (1981). Stigma and employability: Discrimination by sex and sexual orientation in the Ontario legal profession. Canadian Review of Sociology/Revue Canadienne de Sociologie, 18(2), 216-221.

Adams, J. (2005). The rule of the father: Patriarchy and patrimonialism in early modern Europe. In C. Camic, P. S. Gorski, \& D. M. Trubek (Eds.), Max Weber's economy and society: A critical companion (pp. 237-266). Palo Alto, CA: Stanford University Press.

Anderson, B. R. (2006). Imagined communities: Reflections on the origin and spread of nationalism. London/New York: Verso.

Anteby, M. (2013). Manufacturing morals: The values of silence in business school education. Chicago: University of Chicago Press.

Armstrong, E. A. (2002). Forging gay identities: Organizing sexuality in San Francisco, 1950-1994. Chicago: University of Chicago Press.

Badgett, M. V. L. (1995). The wage effects of sexual orientation discrimination. Industrial and Labor Relations Review, 48(4), 726-739.

Badgett, M. V. L. (1996). Employment and sexual orientation: Disclosure and discrimination in the workplace. Journal of Gay E Lesbian Social Services, 4(4), 29-52.

Badgett, M. V. L. (2002). Money, myths, and change: The economic lives of lesbians and gay men. Chicago: University of Chicago Press.

Bailey, J. M., \& Oberschneider, M. (1997). Sexual orientation and professional dance. Archives of Sexual Behavior, 26(4), 433-444.

Bailey, R. W. (1999). Gay politics, urban politics: Identity and economics in the urban setting. New York: Columbia University Press.

Baker, A. J. (1982). The problem of authority in radical movement groups: A case study of lesbian-feminist organization. The Journal of Applied Behavioral Science, 18(3), 323-341.

Barton, B. (2006). Stripped: Inside the lives of exotic dancers. New York: New York University Press.

Barton, B. (2012). Pray the gay away: The extraordinary lives of Bible belt Gays. New York: New York University Press.

Battilana, J., Anteby, M., \& Sengul, M. (2010). The circulation of ideas across academic communities: When locals re-import exported ideas. Organization Studies, 31(6), 695-713.

Baumle, A. K., Compton, D. R., \& Poston, D. L. (2009). Same-sex partners: The demography of sexual orientation. Albany: SUNY Press.

Bearman, P., \& Brückner, H. (2002). Opposite-sex twins and adolescent same-sex attraction. American Journal of Sociology, 107(5), 1179-1205.

Belkin, A., \& Levitt, M. (2001). Homosexuality and the Israel defense forces: Did lifting the gay ban undermine military performance? Armed Forces $\mathcal{E}$ Society, 27(4), 541-565.
Berdahl, J. L., Magley, V. J., \& Waldo, C. R. (1996). The sexual harassment of men? Psychology of Women Quarterly, 20(4), 527-547.

Berdie, R. F. (1959). A femininity adjective check list. Journal of Applied Psychology, 43(5), 327-333.

Berg, N., \& Lien, D. (2002). Measuring the effect of sexual orientation on income: Evidence of discrimination? Contemporary Economic Policy, 20(4), 394-414.

Bergler, E. (1960). Psychiatric factors in the decline of an industry. Diseases of the Nervous System, 21, 461-463.

Bernstein, M., \& Kostelac, C. (2002). Lavender and blue: Attitudes about homosexuality and behavior toward lesbians and gay men among police officers. Journal of Contemporary Criminal Justice, 18(3), 302-328.

Bérubé, A. (1990). Coming out under fire: The history of gay men and women in World War Two. New York: Free Press.

Bérubé, A. (2011). "Queer work" and labor history. In My desire for history: essays in gay, community, and labor history (pp. 259-269). Chapel Hill: University of North Carolina Press.

Bilimoria, D., \& Stewart, A. J. (2009). “Don't Ask, Don't Tell”: The academic climate for lesbian, gay, bisexual, and transgender faculty in science and engineering. National Women's Studies Association Journal, 21(2), 85-103.

Black, D. A., Makar, H. R., Sanders, S. G., \& Taylor, L. J. (2003). The earnings effects of sexual orientation. Industrial and Labor Relations Review, 56(3), 449-469.

Black, D., Gates, G., Sanders, S., \& Taylor, L. (2000). Demographics of the gay and lesbian population in the United States: Evidence from available systematic data sources. Demography, 37(2), 139-154.

Blandford, J. M. (2003). The nexus of sexual orientation and gender in the determination of earnings. Industrial and Labor Relations Review, 56(4), 622-642.

Boatwright, K. J., Gilbert, M. S., Forrest, L., \& Ketzenberger, K. (1996). Impact of identity development upon career trajectory: Listening to the voices of lesbian women. Journal of Vocational Behavior, 48(2), 210-228.

Boswell, J. (1980). Christianity, social tolerance, and homosexuality: Gay people in Western Europe from the beginning of the Christian Era to the fourteenth century. Chicago: University of Chicago Press.

Bowen, F., \& Blackmon, K. (2003). Spirals of silence: The dynamic effects of diversity on organizational voice. Journal of Management Studies, 40(6), 1393-1417.

Brander Rasmussen, B. (Ed.). (2001). The making and unmaking of whiteness, Durham, NC: Duke University Press.

Breines, W. (1982). Community and organization in the new left, 1962-1968: The great refusal. New York/South Hadley, MA: Praeger/JF Bergin.

Brekhus, W. (1996). Social marking and the mental coloring of identity: Sexual identity construction and maintenance in the United States. Sociological Forum, 11(3), 497-522.

Brooten, B. J. (1996). Love between women: Early Christian responses to female homoeroticism. Chicago: University of Chicago Press.

Burgoon, J. K., Parrott, R., Poire, B. A. L., Kelley, D. L., Walther, J. B., \& Perry, D. (1989). Maintaining and restoring privacy through communication in different types of relationships. Journal of Social and Personal Relationships, 6(2), 131-158.

Burke, M. E. (1993). Coming out of the blue: British police officers talk about their lives in "the job" as lesbians, gays and bisexuals. London/New York: Cassell.

Burks, D. J. (2011). Lesbian, gay, and bisexual victimization in the military: An unintended consequence of “Don't Ask, Don't Tell”? American Psychologist, 66(7), 604-613.

Button, S. B. (2001). Organizational efforts to affirm sexual diversity: A crosslevel examination. Journal of Applied Psychology, 86(1), 17-28.

Calás, M. B., \& Smircich (2006). From the "woman's point of view" ten years later: Towards a feminist organization studies. In S. R. Clegg (Ed.), The SAGE handbook of organization studies (pp. 284-346). Thousand Oaks, CA: Sage.

Cass, V. C. (1984). Homosexual identity: A concept in need of definition. Journal of Homosexuality, 9(2-3), 105-126.

Chauncey, G. (1982). From sexual inversion to homosexuality: Medicine and the changing conceptualization of female deviance. Salmagundi, (58/59), 114-146.

Chauncey, G. (1994). Gay New York: Gender, urban culture, and the makings of the gay male world, 1890-1940. New York: Basic Books.

Chetkovich, C. A. (1997). Real heat: Gender and race in the urban fire service. New Brunswick, NJ: Rutgers University Press.

Chodorow, N. (1978). The reproduction of mothering: Psychoanalysis and the sociology of gender. Berkeley, CA: University of California Press.

Chrobot-Mason, D., Button, S. B., \& DiClementi, J. D. (2001). Sexual identity management strategies: An exploration of antecedents and consequences. Sex Roles, 45(5-6), 321-336.

Chuang, Y.-T., Church, R., \& Ophir, R. (2011). Taking sides: The interactive influences of institutional mechanisms on the adoption of same-sex 
partner health benefits by Fortune 500 corporations, 1990-2003. Organization Science, 22(1), 190-209.

Clair, J. A., Beatty, J. E., \& MacLean, T. L. (2005). Out of sight but not out of mind: Managing invisible social identities in the workplace. Academy of Management Review, 30(1), 78-95.

Cory, D. W. (1951). The homosexual in America: A subjective approach. New York: Greenberg.

Corzine, J., \& Kirby, R. (1977). Cruising the truckers: Sexual encounters in a highway rest area. Urban Life, 6(2), 171-192.

Creed, W. E. D. (2003). Voice lessons: Tempered radicalism and the use of voice and silence. Journal of Management Studies, 40(6), 1503-1536.

Creed, W. E. D. (2006). Seven conversations about the same thing. In Alison Konrad, Pushkala Prasad, K. Judith, \& Pringle (Eds.), Handbook of workplace diversity (pp. 371-400). Thousand Oaks, CA: Sage.

Creed, W. E. D., Dejordy, R., \& Lok, J. (2010). Being the change: Resolving institutional contradiction through identity work. Academy of Management Journal, 53(6), 1336-1364.

Creed, W. E. D., \& Scully, M. A. (2000). Songs of ourselves: Employees' deployment of social identity in workplace encounters. Journal of Management Inquiry, 9(4), 391-412.

Creed, W. E. D., Scully, M. A., \& Austin, J. R. (2002). Clothes make the person? The tailoring of legitimating accounts and the social construction of identity. Organization Science, 13(5), 475-496.

Croteau, J. M. (1996). Research on the work experiences of lesbian, gay, and bisexual people: An integrative review of methodology and findings. Journal of Vocational Behavior, 48(2), 195-209.

D'Augelli, A. R., \& Grossman, A. H. (2001). Disclosure of sexual orientation, victimization, and mental health among lesbian, gay, and bisexual older adults. Journal of Interpersonal Violence, 16(10), 1008-1027.

Daniel, C., Arzoglou, E., \& Lamont, M. (2011). European workers: Meaningmaking beings. In D. Brady (Ed.), Comparing European Workers Part B: Policies and institutions (pp. 287-312). Bingley, UK: Emerald Group Publishing.

Davids, A., Joelson, M., \& McArthur, C. (1956). Rorschach and TAT indices of homosexuality in overt homosexuals, neurotics, and normal males. Journal of Abnormal and Social Psychology, 53(2), 161-172.

Day, N. E., \& Greene, P. G. (2008). A case for sexual orientation diversity management in small and large organizations. Human Resource Management, 47(3), 637-654.

Day, N. E., \& Schoenrade, P. (1997). Staying in the closet versus coming out: Relationships between communication about sexual orientation and work attitudes. Personnel Psychology, 50(1), 147-163.

Day, N. E., \& Schoenrade, P. (2000). The relationship among reported disclosure of sexual orientation, anti-discrimination policies, top management support and work attitudes of gay and lesbian employees. Personnel Review, 29(3), 346-363.

Deitch, E. A., Butz, R. M., \& Brief, A. (2004). Out of the closet and out of a job? The nature, import, and causes of sexual orientation discrimination in the workplace. In R. W. Griffin \& A. O'Leary-Kelly (Eds.), The dark side of organizational behavior (pp. 187-234). San Francisco: John Wiley \& Sons.

Dejordy, R. (2008). Just passing through: Stigma, passing, and identity decoupling in the workplace. Group \& Organization Management, 33(5), 504-531.

Diamant, L. (Ed.). (1993). Homosexual issues in the workplace. Washington: Taylor \& Francis.

Diamond, L. M. (2008). Sexual fluidity: Understanding women's love and desire. Cambridge, MA: Harvard University Press.

Driscoll, J. M., Kelley, F. A., \& Fassinger, R. E. (1996). Lesbian identity and disclosure in the workplace: Relation to occupational stress and satisfaction. Journal of Vocational Behavior, 48(2), 229-242.

Drydakis, N. (2009). Sexual orientation discrimination in the labour market. Labour Economics, 16(4), 364-372.

Duberman, M. B. (1993). Stonewall. New York: Dutton.

Dyer, R. (1997). White. London/New York: Routledge.

Ellis, A. (1959). Homosexuality and creativity. Journal of Clinical Psychology, 15(4), 376-379

Ellis, A. L., \& Riggle, E. D. B. (1996). The relation of job satisfaction and degree of openness about one's sexual orientation for lesbians and gay men. Journal of Homosexuality, 30(2), 75-85.

Ellis, H. (1895). Sexual inversion in women. Alienist and Neurologist, 16, 141 158.

Ellis, H. (1897). Sexual inversion. London: F A Davis Company.

Elsbach, K. D., \& Sutton, R. I. (1992). Acquiring organizational legitimacy through illegitimate actions: A marriage of institutional and impression management theories. Academy of Management Journal, 35(4), 699-738.

Ely, R. J., \& Meyerson, D. E. (2010). An organizational approach to undoing gender: The unlikely case of offshore oil platforms. Research in Organizational Behavior, 30, 3-34.
Embrick, D. G., Walther, C. S., \& Wickens, C. M. (2007). Working class masculinity: Keeping gay men and lesbians out of the workplace. Sex Roles, 56(11-12), 757-766.

D’Emilio, J. (1983). Capitalism and gay identity. In K. V. Hansen \& A. I. Garey (Eds.), Families in the US: Kinship and domestic politics (pp. 131-141). Philadelphia: Temple University Press.

Escoffier, J. (1975). Stigmas, work environment, and economic discrimination against homosexuals. Homosexual Counseling Journal, 8-17.

Escoffier, J. (2003). Gay-for-pay: Straight men and the making of gay pornography. Qualitative Sociology, 26(4), 531-555.

Evans, N. J., \& D’Augelli, A. R. (1996). Lesbians, gay men, and bisexual people in college. In The lives of lesbians, gays, and bisexuals: Children to adults (pp. 201-226). Orlando: Harcourt Brace College Publishers.

Faderman, L. (2011). Odd girls and twilight lovers: A history of lesbian life in twentieth-century America. New York: Columbia University Press.

Fassin, E. (2010). National identities and transnational intimacies: Sexual democracy and the politics of immigration in Europe. Public Culture, 22(3), 507-529.

Fenichel, O. (1946). On acting. Psychoanalytic Quarterly, 15, 144-160.

Ferfolja, T. (2009). State of the field review: Stories so far: An overview of the research on lesbian teachers. Sexualities, 12(3), 378-396.

Ferree, M. M., \& Martin, P. Y. (Eds.). (1995). Feminist organizations: Harvest of the new women's movement. Philadelphia: Temple University Press.

Fine, G. A. (1983). Shared fantasy: Role-playing games as social worlds. Chicago: University of Chicago Press.

Fleming, P., \& Sturdy, A. (2011). "Being yourself" in the electronic sweatshop: New forms of normative control. Human Relations, 64(2), 177-200.

Freedman, E. B. (1996). The prison lesbian: Race, class, and the construction of the aggressive female homosexual, 1915-1965. Feminist Studies, 22(2), 397-423.

Friskopp, A. (1995). Straight jobs, gay lives: Gay and lesbian professionals, the Harvard Business School, and the American Workplace. New York: Scribner.

Gagnon, J. H. (1974). Sexual conduct: The social sources of human sexuality. London: Hutchinson.

Gagnon, J. H. (1990). The explicit and implicit use of the scripting perspective in sex research. Annual Review of Sex Research, 1(1), 1-43.

Galupo, M. P. (2007). Friendship patterns of sexual minority individuals in adulthood. Journal of Social and Personal Relationships, 24(1), 139-151.

Gamson, J. (1995). Must identity movements self-destruct? A queer dilemma. Social problems, 390-407.

Gamson, J. (1996). The organizational shaping of collective identity: The case of lesbian and gay film festivals in New York. Sociological Forum, 11(2), 231-261.

Gates, G. J. (2011). How many people are lesbian, gay, bisexual and transgender? Los Angeles: Williams Institute, UCLA.

Ghosh, A. (2012). Leveraging sexual orientation workforce diversity through identity deployment. In C. L. Scott \& M. Y. Byrd (Eds.), Handbook of research on workforce diversity in a global society: Technologies and concepts. Hershey, PA: IGI Global.

Gilligan, C. (1982). In a different voice: Psychological theory and women's development. Cambridge, MA: Harvard University Press.

Githens, R. P. (2009). Capitalism, identity politics, and queerness converge: LGBT employee resource groups. New Horizons in Adult Education and Human Resource Development, 23(3), 18-31.

Githens, R. P., \& Aragon, S. R. (2009). LGBT employee groups: Goals and organizational structures. Advances in Developing Human Resources, 11(1), 121-135. Retrieved June 12, 2014, from.

Goffman, E. (1963). Stigma: Notes on the management of spoiled identity. Spectrum book. Englewood Cliffs, NJ: Prentice-Hall.

Goffman, E. (1974). Frame analysis: An essay on the organization of experience. Cambridge, MA: Harvard University Press.

Gonsiorek, J. C., \& Weinrich, J. D. (1991). The definition and scope of sexual orientation. Sage Publications Inc.

Goode, E. (1974). Homosexual encounters in a highway rest stop. Sexual deviance and sexual deviants. New York: Morrow.

Goode, E. (1981). Comments on the homosexual role. Journal of Sex Research, $17(1), 54-65$.

Gould, D. B. (2009). Moving politics: Emotion and ACT UP's fight against AIDS Chicago: University of Chicago Press.

Green, R., \& Money, J. (1966). Stage-acting, role-taking, and effeminate impersonation during boyhood. Archives of General Psychiatry, 15(5), $535-538$.

Greenberg, D. F. (1988). The construction of homosexuality. Chicago: University of Chicago Press.

Griffin, P. (1991). From hiding out to coming out: Empowering lesbian and gay educators. Journal of Homosexuality, 22(3/4), 167-196.

Griffith, K. H., \& Hebl, M. R. (2002). The disclosure dilemma for gay men and lesbians: "Coming out" at work. Journal of Applied Psychology, 87(6), $1191-1199$. 
Group for the Advancement of Psychiatry (Committee on Cooperation with Governmental Agencies) (1955). Report on homosexuality with particular emphasis on this problem in governmental agencies (Rep. No. 30). New York: Group for the Advancement of Psychiatry.

Halberstam, J. (2005). In a queer time and place: Transgender bodies, subcultural lives. Sexual cultures. New York: New York University Press.

Halbwachs, M. (1980). The collective memory. New York: Harper \& Row.

Hall, M. (1989). Private experiences in the public domain: Lesbians in organizations. In The sexuality of organization (pp. 125-138). London: Sage.

Hamer, D. H., Hu, S., Magnuson, V. L., Hu, N., \& Pattatucci, A. M. (1993). A linkage between DNA markers on the X chromosome and male sexual orientation. Science, 261(5119), 321-327.

Harbeck, K. M. (1991). Coming out of the classroom closet: Gay and lesbian students, teachers, and curricula. New York: Harrington Park Press.

Harding, T. (2007). The construction of men who are nurses as gay. Journal of Advanced Nursing, 60(6), 636-644.

Harris, K. M. (2009). The national longitudinal study of adolescent health (add health), Waves I \&' II, 1994-1996: Wave III, 2001-2002: Wave IV, 20072009. Chapel Hill, NC: Carolina Population Center, University of North Carolina at Chapel Hill.

Haselkorn, H. (1953). The vocational interests of a group of homosexuals (Ph.D. thesis) New York, United States: New York University.

Hebl, M. R., Foster, J. B., Mannix, L. M., \& Dovidio, J. F. (2002). Formal and interpersonal discrimination: A field study of bias toward homosexual applicants. Personality and Social Psychology Bulletin, 28(6), 815-825

Hebl, M. R., Tonidandel, S., \& Ruggs, E. N. (2012). The impact of like-mentors for gay/lesbian employees. Human Performance, 25(1), 52-71.

Hekma, G. (2007). Homosexuality. In G. Ritzer (Ed.), Blackwell encyclopedia of sociology (5, pp. 2157-2163). Malden, MA: Blackwell Publishing.

Henley, N. M., \& Pincus, F. (1978). Interrelationship of sexist, racist, and antihomosexual attitudes. Psychological Reports, 42(1), 83-90.

Herek, G. M. (1984). Beyond "homophobia": A social psychological perspective on attitudes toward lesbians and gay men. Journal of Homosexuality $10(1-2), 1-21$.

Herek, G. M. (1996). Why tell if you're not asked? Self-disclosure, intergroup contact, and heterosexuals' attitudes toward lesbians and gay men. In J. B. Jobe, R. M. Carney, \& G. M. Herek (Eds.), Out in force: Sexual orientation and the military (pp. 197-225). Chicago: University of Chicago Press.

Herek, G. M., \& Capitanio, J. P. (1999). AIDS stigma and sexual prejudice. American Behavioral Scientist, 42(7), 1130-1147.

Herek, G. M., Jobe, J. B., \& Carney, R. M. (1996). Out in force: Sexual orientation and the military. Chicago: University of Chicago Press.

Herek, G. M., \& McLemore, K. A. (2013). Sexual prejudice. Annual Review of Psychology, 64(1), 309-333.

Hershberger, S. L. (1997). A twin registry study of male and female sexual orientation. Journal of Sex Research, 34(2), 212-222.

Hetherington, C., \& Orzek, A. (1989). Career counseling and life planning with lesbian women. Journal of Counseling \& Development, 68(1.).

Hewitt, C. (1995). The socioeconomic position of gay men: A review of the evidence. American Journal of Economics and Sociology, 54(4), 461-479.

Hochschild, A. R. (1983). The managed heart: Commercialization of human feeling. Berkeley: University of California Press.

Hooker, E. (1957). The adjustment of the male overt homosexual. Journal of Projective Techniques, 21(1), 18-31.

Hudson, B. A., \& Okhuysen, G. A. (2009). Not with a ten-foot pole: Core stigma, stigma transfer, and improbable persistence of men's bathhouses. Organization Science, 20(1), 134-153.

Huffman, A. H. Watrous-Rodriguez, K. M., \& King. E. B. (2008). Supporting a diverse workforce: What type of support is most meaningful for lesbian and gay employees? Human Resource Management, 47(2), 237-253.

Human Rights Campaign (2014). Corporate equality index 2014: Rating American workplaces on lesbian, gay, bisexual and transgender equality. Washington, DC

Humphreys, L. (1975). Tearoom trade: Impersonal sex in public places. New York: Aldine Pub Co.

Hunter, M. A. (2010). All the gays are white and all the blacks are straight: Black gay males, identity and community. Sexuality Research \& Social Policy, 7(2), 81-92.

Kaplan, S. (2008). Framing contexts: Strategy making under uncertainty. Organization Science, 19(5), 729-752.

King, B. G., \& Soule, S. A. (2007). Social movements as extra-institutional entrepreneurs: The effect of protests on stock price returns. Administrative Science Quarterly, 52(3), 413-442.

King, E. B., Mohr, J., Peddie, C., Kendra, M., \& Jones, K. (2014). Predictors of identity management: An exploratory experience-sampling study of lesbian, gay, and bisexual workers. Journal of Management (in press).

King, E. B., Reilly, C., \& Hebl, M. (2008). The best of times, the worst of times: Exploring dual perspectives of "coming out" in the workplace. Group \& Organization Management, 33(5), 566-601.
Kinsey, A. C. (1948). Sexual behavior in the human male. Philadelphia: WB Saunders $\mathrm{Co}_{0}$

Kissen, R. M. (1996). The last closet: The real lives of lesbian and gay teachers. Portsmouth, NH: Heinemann.

Klawitter, M. M., \& Flatt, V. (1998). The effects of state and local antidiscrimination policies on earnings for gays and lesbians. Journal of Policy Analysis and Management, 17(4), 658-686.

Klein, F. (1993). The bisexual option. The Haworth Press.

Köllen, T. (2013). Bisexuality and diversity management-Addressing the B in LGBT as a relevant "sexual orientation" in the workplace. Journal of Bisexuality, 13(1), 122-137.

von Krafft-Ebing, R. (1886). Psychopathia sexualis. Stuttgart: F Enke.

Kunzel, R. G. (2002). Situating sex: Prison sexual culture in the mid-twentieth-century United States. GLQ: A Journal of Lesbian and Gay Studies, 8(3), $253-270$

Lapovsky Kennedy, E., \& Davis, M. D. (1993). Boots of leather, slippers of gold: The history of a lesbian community. New York: Routledge.

Laumann, E. O., Gagnon, J. H., Michael, R. T., \& Michaels, S. (1994). The social organization of sexuality: Sexual practices in the United States. Chicago: University of Chicago Press.

Lerum, K. (2004). Sexuality, power, and camaraderie in service work. Gender and Society, 18(6), 756-776

Lever, M. (1985). Les Bûchers de Sodome: Histoire des "Infâmes". Paris: Fayard.

Levine, M. P. (1979). Gay ghetto. In Gay M: The sociology of male homosexuality (pp. 182-204). New York: Harper, Row.

Levine, M. P., \& Leonard, R. (1984). Discrimination against lesbians in the work force. Signs, 9(4), 700-710

Lewis, G. B. (2010). Modeling nonprofit employment: Why do so many lesbians and gay men work for nonprofit organizations? Administration E' Society, 42(6), 720-748.

Lewis, G. B., \& Ng, E. (2013). Sexual orientation, work values, pay, and preference for public and nonprofit employment: Evidence from Canadian postsecondary students. Canadian Public Administration/Administration Publique du Canada, 56(4), 542-564.

Lewis, G. B., \& Pitts, D. W. (2011). Representation of lesbians and gay men in federal, state, and local bureaucracies. Journal of Public Administration Research \& Theory, 21(1), 159-180.

Leznoff, M. (1956). Interviewing homosexuals. American Journal of Sociology, 62(2), 202-204.

Leznoff, M., \& Westley, W. A. (1955). The homosexual community. Social Problems, 3, 257-263.

Lichtenstein, P. M. (1921). The "fairy" and the lady lover. Medical Review of Reviews, 27(370), 373-374.

Logan, T. D. (2010). Personal characteristics, sexual behaviors, and male sex work: A quantitative approach. American Sociological Review, 75(5), 679704.

Macalpine, M., \& Marsh, S. (2005). “On being white: There’s nothing I can say": Exploring whiteness and power in organizations. Management Learning, 36(4), 429-450.

Martin, J., Knopoff, K., \& Beckman, C. (1998). An alternative to bureaucratic impersonality and emotional labor: Bounded emotionality at The Body Shop. Administrative Science Quarterly, 43(2), 429-469.

Martin, S. E. (1980). Breaking and entering: Policewomen on patrol. Berkeley: University of California Press.

Matthews, C., \& Hill, C. (2011). Gay until proven straight: Exploring perceptions of male interior designers from male practitioner and student perspectives. Journal of Interior Design, 36(3), 15-34.

McCaghy, C. H., \& Skipper, J. K., Jr. (1969). Lesbian behavior as an adaptation to the occupation of stripping. Social Problems, 17(2), 262-270.

McGuire, T. R. (1995). Is homosexuality genetic? Journal of Homosexuality, 28(1-2), 115-146.

McIntosh, M. (1968). The homosexual role. Social Problems, 16(2), 182192.

Miller, G. V. (1995). The gay male's odyssey in the corporate world: From disempowerment to empowerment. New York: Haworth Press.

Miller, S. L., Forest, K. B., \& Jurik, N. C. (2003). Diversity in blue: Lesbian and gay police officers in a masculine occupation. Men and Masculinities, 5(4), 355-385.

Murray, S. O. (1991). "Homosexual occupations" in Mesoamerica? Journal of Homosexuality, 21(4), 57-66.

Nardi, P. M. (1999). Gay men's friendships: Invincible communities. Chicago: University of Chicago Press.

Negro, G., Carroll, G. R., \& Perreti, F. (2013). Challenger groups, commercial organizations, and policy enactment: Local lesbian/gay rights ordinances in the United States from 1972 to 2008. American Journal of Sociology, 119(3), 790-832.

Ng, E., Schweitzer, L., \& Lyons, S. T. (2012). Anticipated discrimination and a career choice in nonprofit: A study of early career lesbian, gay, bisexual, transgendered (LGBT) job seekers. Review of Public Personnel Administration, 32(4), 332-352. 
Olick, J. K. (2007). Collective memory and nonpublic opinion: A historical note on a methodological controversy about a political problem. Symbolic Interaction, 30(1), 41-55.

Olson, M. R. (1987). A study of gay and lesbian teachers. Journal of Homosexuality, 13(4), 73-81.

Omark, R. C. (1978). A comment on the homosexual role. Journal of Sex Research, 14(4), 273-274.

Orzechowicz, D. (2010). Fierce bitches on Tranny Lane: Gender, sexuality, culture, and the closet in theme park parades. Research in the Sociology of Work, 20, 227-252.

Ozturk, M. B. (2011). Sexual orientation discrimination: Exploring the experiences of lesbian, gay and bisexual employees in Turkey. Human Relations, 64(8), 1099-1118.

Padilla, M. B. (2007). "Western Union daddies" and their quest for authenticity: An ethnographic study of the Dominican gay sex tourism industry. Journal of Homosexuality, 53(1-2), 241-275.

Palmer, A. (1993). Less equal than others: A survey of lesbians and gay men at work. London: Stonewall.

Parker, D. A., \& De Cecco, J. P. (1995). Sexual expression: A global perspective. Journal of Homosexuality, 28(3-4), 427-430.

Parker, W. (1971). Homosexuality: A selective bibliography of over 3,000 items. Metuchen, NJ: Scarecrow Press.

Penn, D. (1995). Queer: Theorizing politics and history. Radical History Review, 1995(62), 24-42.

Perkins, K. B., \& Skipper, J. K. (1981). Gay pornographic and sex paraphernalia shops: An ethnography of expressive work settings. Deviant Behavior 2(2), 187-199.

Plummer, K. (1982). Symbolic interactionism and sexual conduct: An emergent perspective. In M. Brake (Ed.), Symbolic interactionism and sexual conduct an emergent perspective (pp. 223-241). New York: Pantheon Books.

Raeburn, N. C. (2004). Changing corporate America from inside out: Lesbian and gay workplace rights. Minneapolis: University of Minnesota Press.

Ragins, B. R. (2004). Sexual orientation in the workplace: The unique work and career experiences of gay, lesbian and bisexual workers. Research in Personnel and Human Resources Management, 23, 35-120.

Ragins, B. R., \& Cornwell, J. M. (2001). Pink triangles: Antecedents and consequences of perceived workplace discrimination against gay and lesbian employees. Journal of Applied Psychology, 86(6), 1244-1261.

Ragins, B. R., Cornwell, J. M., \& Miller, J. S. (2003). Heterosexism in the workplace: Do race and gender matter? Group \& Organization Management, 28(1), 45-74.

Ragins, B. R., Singh, R., \& Cornwell, J. M. (2007). Making the invisible visible: Fear and disclosure of sexual orientation at work. Journal of Applied Psychology, 92(4), 1103-1118.

Ramarajan, L., \& Reid, E. M. (2013). Shattering the myth of separate worlds: Negotiating non-work identities at work. Academy of Management Review, 38(4), 621-644.

Reid, E. M. (2011). Passing as superman: The ideal worker and men's professional identities. Academy of Management Proceedings.

Reiss, A. J. J. (1961). The social integration of queers and peers. Social Problems, 9, 102-120.

Reitzell, J. M. (1949). A comparative study of hysterics, homosexuals and alcoholics using content analysis of Rorschach responses. Rorschach Research Exchange and Journal of Projective Techniques, 13(2), 127-141.

Reitzes, D. C., \& Diver, J. K. (1982). Gay bars as deviant community organizations: The management of interactions with outsiders. Deviant Behavior, 4, 1-18.

Risman, B., \& Schwartz, P. (1988). Sociological research on male and female homosexuality. Annual Review of Sociology, 14(1), 125-147.

Rumens, N. (2010). Firm friends: Exploring the supportive components in gay men's workplace friendships. The Sociological Review, 58(1), 135155.

Rumens, N. (2011). Queer company: The role and meaning of friendship in gay men's work lives. Burlington, VT: Ashgate.

Rumens, N. (2012). Queering cross-sex friendships: An analysis of gay and bisexual men's workplace friendships with heterosexual women. $\mathrm{Hu}$ man Relations, 65(8), 955-978.

Rumens, N., \& Broomfield, J. (2012). Gay men in the police: Identity disclosure and management issues. Human Resource Management Journal, 22(3), 283-298.

Ryan, A. M., \& Wessel, J. L. (2012). Sexual orientation harassment in the workplace: When do observers intervene? Journal of Organizational Behavior, 33(4), 488-509.

Savin-Williams, R. C. (1993). Personal reflections on coming out, prejudice, and homophobia in the academic workplace. Homosexual issues in the workplace, 225-241.

Schneider, B. E. (1986). Coming out at work: Bridging the private/public gap. Work and Occupations, 13(4), 463-487.
Schultz, V. (2003). The sanitized workplace. Yale Law Journal, 112(8), 2061 2193.

Scully, M. A., \& Segal, A. (2002). Passion with an umbrella: Grassroots activists in the work place. In M. Lounsbury, \& M. J. Ventresca (Eds.), Social structure and organizations revisited, research in the sociology of organizations (19, pp. 125-168). Emerald Group Publishing.

Sears, J. T. (2002). The institutional climate for lesbian, gay and bisexual education faculty. Journal of Homosexuality, 43(1), 11-37.

Sedlovskaya, A., Purdie-Vaughns, V., Eibach, R. P., LaFrance, M., RomeroCanyas, R., \& Camp, N. P. (2013). Internalizing the closet: Concealment heightens the cognitive distinction between public and private selves. Journal of Personality and Social Psychology, 104(4), 695-715.

Shallenberger, D. (1992). Feelings about a Disneyland visit. Journal of Management Inquiry, 1(4), 278-287.

Shallenberger, D. (1994). Professional and openly gay: A narrative study of the experience. Journal of Management Inquiry, 3(2), 119-142.

Shilts, R. (1982). The mayor of Castro street: The life and times of Harvey milk. New York: St Martin's Press.

Shilts, R. (1987). And the band played on: Politics, people, and the AIDS epidemic. New York: St Martin's Press.

Shilts, R. (1993). Conduct unbecoming: Lesbians and gays in the U.S. Military, Vietnam to the Persian Gulf. New York: St Martin's Press.

Simon, W., \& Gagnon, J. H. (1967). Homosexuality: The formulation of a sociological perspective. Journal of Health and Social Behavior, 8(3), 177 185.

Simonds, W. (1996). Abortion at work: Ideology and practice in a feminist clinic. New Brunswick, NJ: Rutgers University Press.

Smith, M. D., Grov, C., Seal, D. W., \& McCall, P. (2013). A social-cognitive analysis of how young men become involved in male escorting. Journal of Sex Research, 50(1), 1-10.

Snape, D. (1995). Discrimination against gay men and lesbians: A study of the nature and extent of discrimination against homosexual men and women in Britain today. London: Social and Community Planning Research.

Some comparisons between male female homosexuals. (1960). Ladder, (September), 4-25.

Some facts about lesbians. (1959). Ladder, (September), 4-26.

Somerville, S. B. (2000). Queering the color line: Race and the invention of homosexuality in American culture. Durham, NC: Duke University Press.

Steakley, J. D. (1997). Per scientiam ad justitiam: Magnus Hirschfeld and the sexual politics of innate homosexuality. In V. A. Rosario (Ed.), Science and homosexualities (pp. 133-154). New York: Routledge.

Stein, E. (1999). The mismeasure of desire: The science, theory and ethics of sexual orientation. Oxford/New York: Oxford University Press.

Storms, M. D. (1980). Theories of sexual orientation. Journal of Personality and Social Psychology, 38(5), 783-792.

Summers, A. (1991). The correspondents of Havelock Ellis. History Workshop, $32,167-183$

Taub, D. E. (1982). Public sociability of college-aged male homosexuals: The gay bar and cruise block. Sociological Spectrum, 291-305.

Taylor, V., \& Raeburn, N. C. (1995). Identity politics as high-risk activism: Career consequences for lesbian, gay, and bisexual sociologists. Social Problems, 42(2), 252-273.

Taylor, V., \& Whittier, N. E. (1992). Collective identity in social movement communities: Lesbian feminist mobilization. In A. D. Morris \& C. M. Mueller (Eds.), Frontiers in social movement theory (pp. 104-129). New Haven: Yale University Press.

The invert his job. (1955 June). Mattachine Review, 15-16.

Tilcsik, A. (2011). Pride and prejudice: Employment discrimination against openly gay men in the United States. American Journal of Sociology, 117(2), 586-626.

Tilcsik, A., Anteby, M., \& Knight, C. (2014). Concealable stigma and occupational segregation: Toward a theory of gay and lesbian occupations (Working paper)

Ueno, K., Peña-Talamantes, A. E., \& Roach, T. A. (2013). Sexual orientation and occupational attainment. Work and Occupations, 40(1), 3-36.

Valocchi, S. (2005). Not yet queer enough: The lessons of queer theory for the sociology of gender and sexuality. Gender \& Society, 19(6), 750-770.

Waldo, C. R., Berdahl, J. L., \& Fitzgerald, L. F. (1998). Are men sexually harassed? If so, by whom?. Law and Human Behavior, 22(1), 59-79.

Walker, E. T. (2012). Social movements, organizations, and fields: A decade of theoretical integration. Contemporary Sociology: A Journal of Reviews, 41(5), 576-587.

Ward, D. A., \& Kassebaum, G. G. (1964). Homosexuality: A mode of adaptation in a prison for women. Social Problems, 12, 159-177.

Ward, E. J. (2008). Respectably queer: Diversity culture in LGBT activist organizations. Nashville: Vanderbilt University Press.

Ward, J., \& Winstanley, D. (2003). The absent presence: Negative space within discourse and the construction of minority sexual identity in the workplace. Human Relations, 56(10), 1255-1280. 
Ward, J., \& Winstanley, D. (2006). Watching the watch: The UK Fire Service and its impact on sexual minorities in the workplace. Gender, Work \& Organization, 13(2), 193-219.

Weeks, J., Heaphy, B., \& Donovan, C.(Eds.).(2001). Same-sexintimacies: Families of choice and other life experiments. London/New York: Routledge.

Weichselbaumer, D. (2003). Sexual orientation discrimination in hiring. Labour Economics, 10(6), 629-642.

Weider, A., Mittelmann, B., Wechsler, D., Wolff, H. G., \& Meixner, M. (1944). The Cornell selectee index: A method for quick testing of selectees for the armed forces. Journal of the American Medical Association, 124(4), 224-228.

Weinberg, G. H. (1972). Society and the healthy homosexual. New York: St Martin's Press.

Weinberg, M. S. (1972). Homosexuality: An annotated bibliography. New York: Harper \& Row

Weinberg, M. S., \& Williams, C. J. (1975). Gay baths and the social organizations of impersonal sex. Social Problems, 23, 124-136.

Weston, K. M., \& Rofel, L. B. (1984). Sexuality, class, and conflict in a lesbian workplace. Signs, 9(4), 623-646.

Wheeler, W. M. (1949). An analysis of Rorschach indices of male homosexuality. Rorschach Research Exchange and Journal of Projective Techniques, 13(2), 97-126

Whitaker, L., Jr. (1961). The use of an extended draw-a-person test to identify homosexual and effeminate men. Journal of Consulting Psychology, 25(6), 482-485

Whitam, F. L. (1977). The homosexual role: A reconsideration. Journal of Sex Research, 13(1), 1-11.
Whitam, F. L. (1986). Male homosexuality in four societies: Brazil, Guatemala, the Philippines, and the United States. New York: Praeger.

Whitam, F. L., \& Dizon, M. J. (1979). Occupational choice and sexual orientation in cross-cultural perspective. International Review of Modern Sociology, 137-149.

Whitehead, N. E. (2011). Neither genes nor choice: Same-sex attraction is mostly a unique reaction to environmental factors. Journal of Human Sexuality, 3, 81-114.

Williams, C., \& Giuffre, P. (2011). From organizational sexuality to queer organizations: Research on homosexuality and the workplace. Sociology Compass, 5(7), 551-563.

Williams, C. L. (2013). The glass escalator, revisited: Gender inequality in neoliberal times. Gender \& Society, 27(5), 609-629.

Williams, C. L., Giuffre, P. A., \& Dellinger, K. (2009). The gay-friendly closet. Sexuality Research E' Social Policy, 6(1), 29-45.

Willis, P. (2012). Witnesses on the periphery: Young lesbian, gay, bisexual and queer employees witnessing homophobic exchanges in Australian workplaces. Human Relations, 65(12), 1589-1610.

Woods, J. D., \& Lucas, J. H. (1993). The corporate closet: The professional lives of gay men in America. New York: Free Press.

Yoshino, K. (2006). Covering: The hidden assault on our civil rights. New York: Random House.

Young-Bruehl, E. (1996). The anatomy of prejudices. Cambridge, MA: Harvard University Press.

Zelizer, V. A. (2009). Intimacy in economic organizations. In N. Bandelj (Ed.), Research in the sociology of work: Economic sociology of work (18, pp. 23-55). .

Zurlinden, J. (1996). Lesbian E' gay nurses. New York: Van Nostrand-Reinhold. 